\title{
Stable carbon isotope gradients in benthic foraminifera as proxy for organic carbon fluxes in the Mediterranean Sea
}

\author{
Marc Theodor ${ }^{1}$, Gerhard Schmiedl ${ }^{1}$, Frans Jorissen ${ }^{2}$, and Andreas Mackensen ${ }^{3}$ \\ ${ }^{1}$ Center for Earth System Research and Sustainability, Institute of Geology, University of Hamburg, \\ Bundesstrasse 55, 20146 Hamburg, Germany \\ ${ }^{2}$ CNRS, UMR 6112, LPG-BIAF, Recent and Fossil Bio-Indicators, Université d'Angers, 2 Boulevard Lavoisier, \\ 49045 Angers CEDEX, France \\ ${ }^{3}$ Alfred Wegener Institute, Helmholtz Centre for Polar and Marine Research, Am Alten Hafen 26, \\ 27568 Bremerhaven, Germany \\ Correspondence to: Marc Theodor (marc.theodor@uni-hamburg.de)
}

Received: 6 June 2016 - Published in Biogeosciences Discuss.: 9 June 2016

Revised: 26 October 2016 - Accepted: 8 November 2016 - Published: 30 November 2016

\begin{abstract}
We have determined stable carbon isotope ratios of epifaunal and shallow infaunal benthic foraminifera in the Mediterranean Sea to relate the inferred gradient of pore water $\delta^{13} \mathrm{C}_{\text {DIC }}$ to varying trophic conditions. This is a prerequisite for developing this difference into a potential transfer function for organic matter flux rates. The data set is based on samples retrieved from a well-defined bathymetric range (400-1500 m water depth) of sub-basins in the western, central, and eastern Mediterranean Sea. Regional contrasts in organic matter fluxes and associated $\delta^{13} \mathrm{C}_{\mathrm{DIC}}$ of pore water are recorded by the $\delta^{13} \mathrm{C}$ difference $\left(\Delta \delta^{13} \mathrm{C}_{\text {Umed-Epi }}\right)$ between the shallow infaunal Uvigerina mediterranea and epifaunal species (Planulina ariminensis, Cibicidoides pachydermus, Cibicides lobatulus). Within epifaunal taxa, the highest $\delta^{13} \mathrm{C}$ values are recorded for $P$. ariminensis, providing the best indicator for bottom water $\delta^{13} \mathrm{C}_{\mathrm{DIC}}$. In contrast, $C$. pachydermus reveals minor pore water effects at the more eutrophic sites. Because of ontogenetic trends in the $\delta^{13} \mathrm{C}$ signal of $U$. mediterranea of up to $1.04 \%$, only tests larger than $600 \mu \mathrm{m}$ were used for the development of the transfer function. The recorded differences in the $\delta^{13} \mathrm{C}$ values of $U$. mediterranea and epifaunal taxa $\left(\Delta \delta^{13} \mathrm{C}_{\text {Umed-Epi }}\right)$ range from -0.46 to $-2.13 \%$, with generally higher offsets at more eutrophic sites. The measured $\delta^{13} \mathrm{C}$ differences are related to site-specific differences in microhabitat, depth of the principal sedimentary redox boundary, and TOC content of the ambient sediment. The $\Delta \delta^{13} \mathrm{C}_{\text {Umed-Epi values reveal a consistent }}$ relation to $\mathrm{C}_{\text {org }}$ fluxes estimated from satellite-derived sur-
\end{abstract}

face water primary production in open-marine settings of the Alboran Sea, Mallorca Channel, Strait of Sicily, and southern Aegean Sea. In contrast, $\Delta \delta^{13} \mathrm{C}_{\text {Umed-Epi values in areas }}$ affected by intense resuspension and riverine organic matter sources of the northern to central Aegean Sea and the canyon systems of the Gulf of Lion suggest higher $\mathrm{C}_{\text {org }}$ fluxes compared to the values based on recent primary production. Taking regional biases and uncertainties into account, we establish a first $\Delta \delta^{13} \mathrm{C}_{\text {Umed-Epi-based transfer function for } \mathrm{C}_{\text {org }}}$ fluxes for the Mediterranean Sea.

\section{Introduction}

The stable isotope composition of benthic foraminifera is used in a wide range of paleoceanographic applications. The $\delta^{18} \mathrm{O}$ signal of benthic foraminifera provides information on bottom water temperature and salinity, and has been applied to estimate global ice volume changes (e.g., Shackleton and Opdyke, 1973; Adkins et al., 2002; Marchitto et al., 2014). The benthic foraminiferal $\delta^{13} \mathrm{C}$ signal is mainly used for the reconstruction of changes in deep-sea circulation, bottom water oxygen concentrations, and organic carbon fluxes to the sea floor (Curry and Lohmann, 1982; Zahn et al., 1986; McCorkle and Emerson, 1988; Mackensen and Bickert, 1999; Pahnke and Zahn, 2005). Recently, more quantitative approaches have been applied to the reconstruction of past changes in deep-water oxygenation (Stott et al., 2000; 
Schmiedl and Mackensen, 2006; Hoogakker et al., 2015). There have also been attempts to use multispecies $\delta^{13} \mathrm{C}$ records to reconstruct past organic carbon fluxes (Zahn et al., 1986; Schilman et al., 2003; Kuhnt et al., 2008). However, all of these studies lack a regional calibration based on living specimens and modern organic carbon flux data.

The $\delta^{13} \mathrm{C}$ gradient of pore water dissolved inorganic carbon (DIC) in the uppermost surface sediment is directly related to the flux and decomposition rates of organic matter (McCorkle and Emerson, 1988; McCorkle et al., 1990; Holsten et al., 2004). With increasing depth in the sediment, more ${ }^{13} \mathrm{C}$ depleted organic matter $\left(\delta^{13} \mathrm{C}\right.$ around -18 to $-23 \%$ o, e.g., Mackensen, 2008) is remineralized by microbial activity (McCorkle et al., 1985). This process results in $\delta^{13} \mathrm{C}_{\text {DIC }}$ pore water depletions of up to $-4 \%$ relative to the bottom water signal (McCorkle and Emerson, 1988; McCorkle et al., 1990; Holsten et al., 2004). The preferential release of ${ }^{12} \mathrm{C}$ to the pore water stops when no more organic matter $(\mathrm{OM})$ is remineralized, which mostly coincides with the total consumption of electron acceptors, of which oxygen, nitrate, and sulfate are the most energy-efficient ones (McCorkle and Emerson, 1988; McCorkle et al., 1990; Koho and Pina-Ochoa, 2012, Hoogakker et al., 2015).

The $\delta^{13} \mathrm{C}_{\text {DIC }}$ pore water gradient is reflected in the $\delta^{13} \mathrm{C}$ signal of benthic foraminifera from defined microhabitats on and below the sediment-water interface (Grossman, 1984a, b; McCorkle et al., 1990, 1997; Rathburn et al., 1996; Mackensen and Licari, 2004; Schmiedl et al., 2004; Fontanier et al., 2006). Although benthic foraminifera can migrate through the sediment (Linke and Lutze, 1993; Ohga and Kitazato, 1997) and living individuals may occur across a relatively wide depth interval, the $\delta^{13} \mathrm{C}$ of a species exhibits relatively little scatter, and all specimens tend to reflect the same calcification depth (Mackensen and Douglas, 1989; McCorkle et al., 1990, 1997; Mackensen et al., 2000; Schmiedl et al., 2004). The study of McCorkle and Emerson (1988) has shown that the difference between $\delta^{13} \mathrm{C}_{\mathrm{DIC}}$ of bottom water and $\delta^{13} \mathrm{C}_{\text {DIC }}$ of pore water at the depth in the sediment where oxygen approaches zero is directly related to the oxygen content of the bottom water mass. Based on this observation, the $\delta^{13} \mathrm{C}$ difference of epifaunal (e.g., Cibicidoides) and deep infaunal (Globobulimina) taxa was used as proxy for the quantification of past changes in deep-water oxygenation (Schmiedl and Mackensen, 2006; Hoogakker et al., 2015). In well-oxygenated bottom waters, enhanced organic matter fluxes and decomposition rates result in steepening $\delta^{13} \mathrm{C}_{\text {DIC }}$ gradients in the uppermost sediment, which is then reflected by the $\delta^{13} \mathrm{C}$ difference between epifaunal and shallow infaunal (e.g., Uvigerina) species (Zahn et al., 1986; Mackensen et al., 2000; Brückner and Mackensen, 2008). A simple relation between observed $\delta^{13} \mathrm{C}$ gradients and organic matter fluxes is obscured by the ability of infaunal species to shift their microhabitat in response to changing trophic conditions (Schmiedl and Mackensen, 2006; Theodor et al., 2016). Interspecific differences in the $\delta^{13} \mathrm{C}$ composition of benthic foraminifera are further influenced by species-specific "vital effects", which can be as large as 1\%o (Schmiedl et al., 2004; McCorkle et al., 2008; Brückner and Mackensen, 2008) and are a reflection of metabolic processes and test calcification rates (McConnaughey, 1989a, b). Of minor impact, but still traceable, is the influence of carbonate ion concentration and alkalinity gradients in pore waters (Bemis et al., 1998). Finally, significant ontogenetic $\delta^{13} \mathrm{C}$ trends have been documented for certain taxa, particularly for the genera Uvigerina and Bolivina (Schmiedl et al., 2004; Schumacher et al., 2010; Theodor et al., 2016).

The complexity of factors influencing the stable isotope composition of deep-sea benthic foraminifera and differences between species in different depths in the sediment motivates isotopic studies on living foraminifera in relation to their biology and microhabitat. In particular, combined ecological and biogeochemical studies on a statistically relevant number of sites and on live specimens from areas with well-defined environmental gradients are required for the establishment of reference data sets and transfer functions that could then be used for a more quantitative assessment of organic matter fluxes. The Mediterranean Sea is particularly suitable for such a study because the present deepsea environments are characterized by systematically high oxygen contents along a gradient of trophic differences. In all basins, subsurface water masses are highly oxygenated with $\mathrm{O}_{2}$ concentrations of greater than $160 \mu \mathrm{mol} \mathrm{kg}^{-1}$ due to frequent replenishment of intermediate water in the Levantine Sea and deep water in the Gulf of Lion, Adriatic Sea, and Aegean Sea (Wüst, 1961; Lascaratos et al., 1999; Pinardi and Masetti, 2000; Tanhua et al., 2013; Pinardi et al., 2015). The inflow of nutrients with Atlantic surface waters causes an overall west-east gradient in primary production, from values of about $225 \mathrm{~g} \mathrm{C} \mathrm{m}^{-2} \mathrm{yr}^{-1}$ in the Alboran Sea to about $40 \mathrm{~g} \mathrm{C} \mathrm{m}^{-2} \mathrm{yr}^{-1}$ in the extremely nutrientdepleted oligotrophic Levantine Basin (Bosc et al., 2004; López-Sandoval et al., 2011; Puyo-Pay et al., 2011; Huertas et al., 2012; Tanhua et al., 2013, Gogou et al., 2014). In areas influenced by nutrient input of larger rivers and Black Sea outflow, primary production can be locally enhanced, for example, leading to a trend of decreasing primary production values along a north-south transect in the Aegean Sea (Lykousis et al., 2002; Skliris et al., 2010). In addition, resuspension and lateral transport of organic matter can lead to locally enhanced food availability in submarine canyons and isolated basins (Puig and Palanques, 1998; Danovaro et al., 1999; Heussner et al., 2006; Canals et al., 2013).

In this study, we have compiled a data set on the stable carbon isotope composition of living and dead individuals of three epifaunal species (Cibicidoides pachydermus, Planulina ariminensis, Cibicides lobatulus), and one shallow infaunal species (Uvigerina mediterranea) from 19 Mediterranean sites. The sites are located in a well-defined depth interval (between 400 and $1500 \mathrm{~m}$ ) and represent a wide range of trophic conditions. Adjusted for ontogenetic effects, 


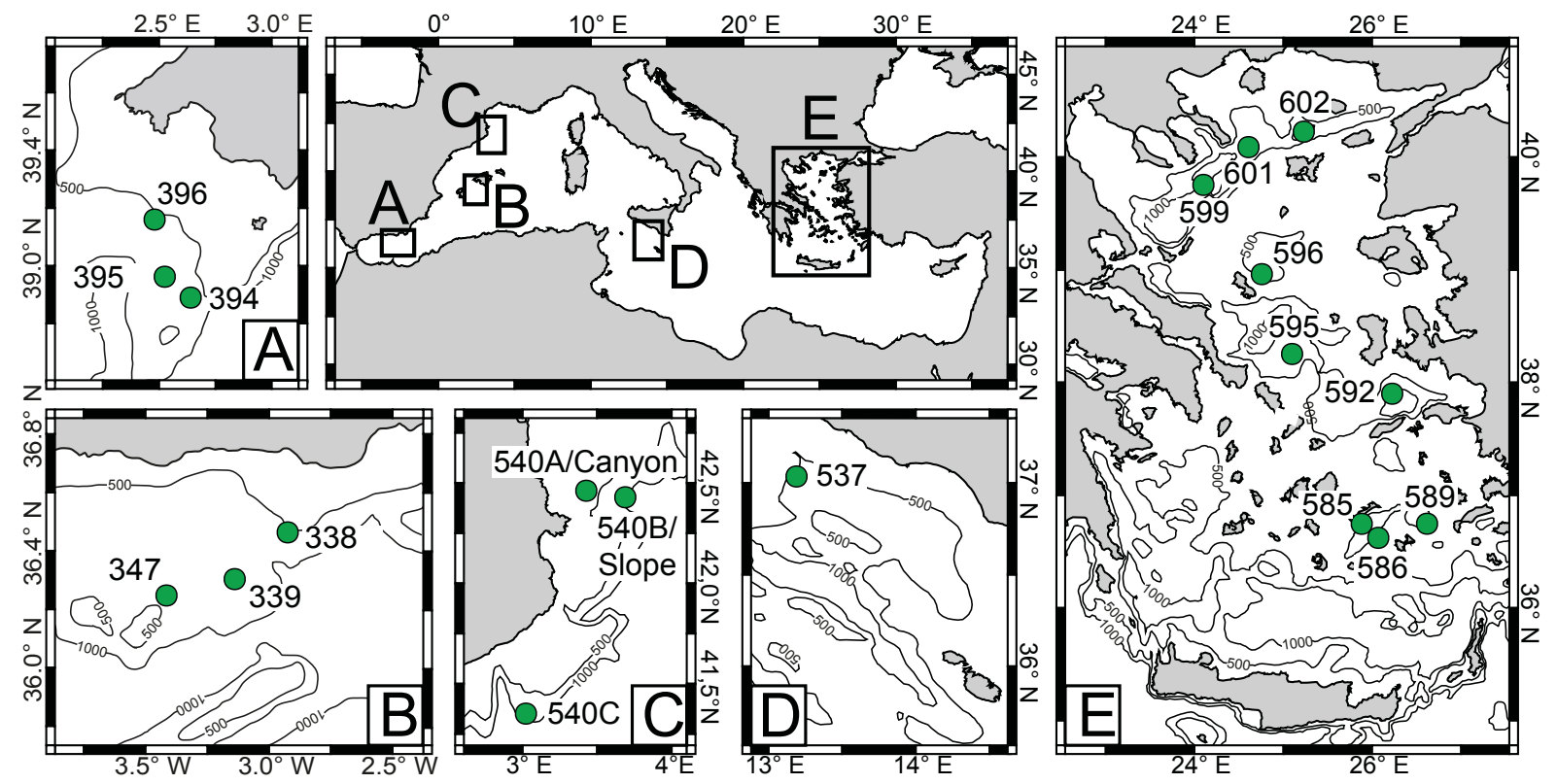

Figure 1. Location of the study areas in the Mediterranean Sea and regional bathymetric maps with locations of sample sites in the (a) Mallorca Channel, (b) Alboran Sea, (c) Gulf of Lion and Spanish slope off Barcelona, (d) Strait of Sicily, and (e) Aegean Sea.

the $\Delta \delta^{13} \mathrm{C}_{\text {Umed-Epi }}$ signal was compared to the microhabitat of $U$. mediterranea, the depth of the main redox boundary, TOC content, and organic carbon flux rates calculated from satellite-derived primary production or (if available) flux measurements from sediment trap studies. Major objective of this study is the development and evaluation of a transfer function for organic matter fluxes applicable to the quantification of past trophic changes in the Mediterranean Sea.

\section{Material and methods}

This study is based on a compilation of new and published isotope data of multicorer samples retrieved from various Mediterranean sub-basins covering a water depth range of 424 to $1466 \mathrm{~m}$ (Table 1). The study areas include the Alboran Sea and the Mallorca Channel (R/V Meteor cruise M69/1 in August 2006, Hübscher et al., 2010; data published in Theodor et al., 2016); the Gulf of Lion, Spanish slope off Barcelona, and Strait of Sicily (M40/4 in February 1998, Hieke et al., 1999; this study and data published in Schmiedl et al., 2004); and the Aegean Sea (M51/3 in November 2001, Hemleben et al., 2003; this study) (Fig. 1). For each station, the sediment color change from yellowish brown to greenish gray was used as an indicator for the change in redox potential from positive to negative values, which serves as an approximation of oxygen consumption and penetration in the surface sediment (Lyle, 1983; Schmiedl et al., 2000).
The upper $10 \mathrm{~cm}$ of the sediment were commonly sliced into 0.5 to $1 \mathrm{~cm}$ intervals (in the Aegean Sea into coarser intervals below $3 \mathrm{~cm}$ ) and all samples were subsequently preserved in rose-bengal-stained alcohol (1.5 g rose bengal per $1 \mathrm{~L}$ of $96 \%$ ethanol) in order to stain cytoplasm of living or recently living foraminifera (Walton, 1952; Bernhard, 2000). In the laboratory, the sediment samples were wet sieved over a $63 \mu \mathrm{m}$ sieve and, after drying at $40^{\circ} \mathrm{C}$, dry sieved over a $150 \mu \mathrm{m}$ (Aegean Sea samples) or $125 \mu \mathrm{m}$ (remaining samples) mesh, respectively. From the coarse fraction of the different down-core intervals, stained individuals of selected epifaunal and shallow infaunal taxa were counted and the median living depths (MLDs; Theodor et al., 2016) were calculated as references for the respective microhabitat preferences. Only tests with at least three subsequent brightly redcolored chambers were considered as living. The low number of stained individuals of epifaunal taxa impeded analyses, except at Site 540B, where stained tests of $C$. pachydermus were available. Likewise, stained tests of $U$. mediterranea were absent at Sites 586 and 589.

For stable isotope measurements, stained tests (and unstained tests if no stained tests were available) of three epifaunal species (C. pachydermus, $P$. ariminensis, $C$. lobatulus) and one shallow infaunal species (U. mediterranea) were selected and each test was measured using an optical micrometer with an accuracy of $10 \mu \mathrm{m}$. In total, 2 stained and 63 unstained epifaunal tests as well as 155 stained and 197 unstained tests of $U$. mediterranea were measured. Individual numbers of tests measured were 1-6 for $C$. pachydermus, $1-$ 5 for $P$. ariminensis, $1-5$ for $C$. lobatulus, and $1-8$ for $U$. mediterranea. The stable carbon and oxygen isotope mea- 


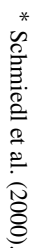

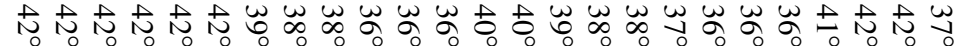

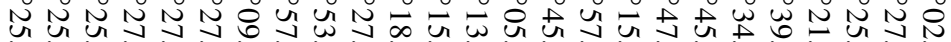

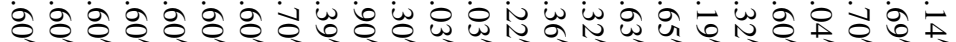
Z Z Z Z Z Z Z Z Z Z Z Z Z Z Z Z Z Z Z Z Z Z Z Z

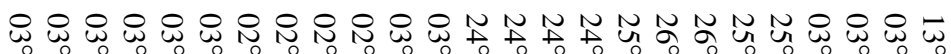

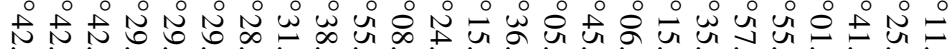
$888 \%$ \& $₫$

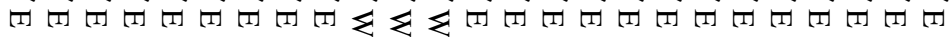

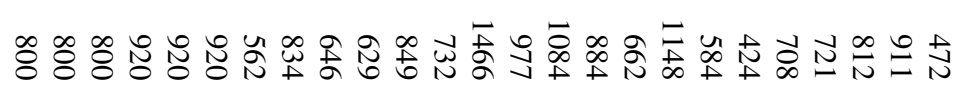

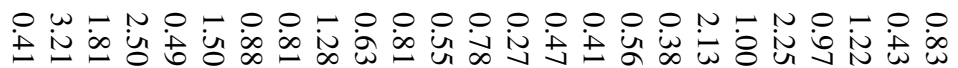

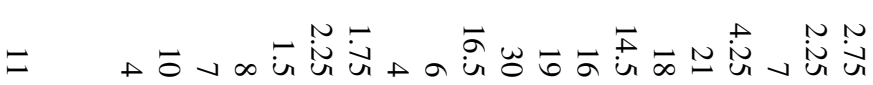

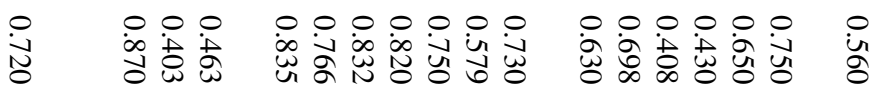

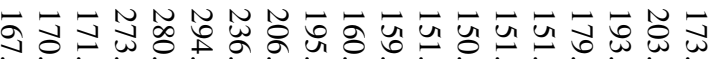
少

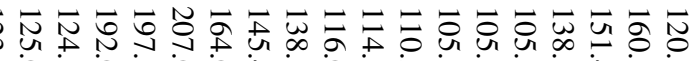

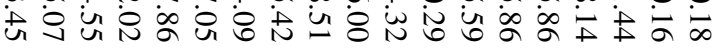

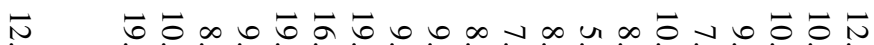

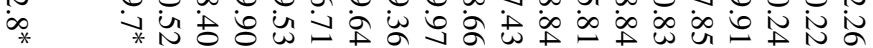

N $\quad$ on $a$ a

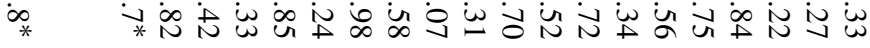

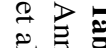

政

家守

常:

要

है

$\approx$

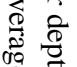

is

융

它 를.

車.

व

के

o $\frac{0}{5}$

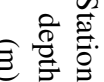

急完

品.

$\stackrel{2}{5}$

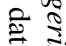

可

웅

$\Omega$

西

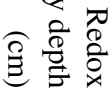

बิ

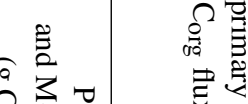

品

ङ

(2)

¿ำ

बै

율

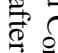

फ़्व

궁

$\stackrel{2}{\circ}$

ᄅै

实总

艺

产完.

了

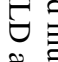

兼

쿵

융 


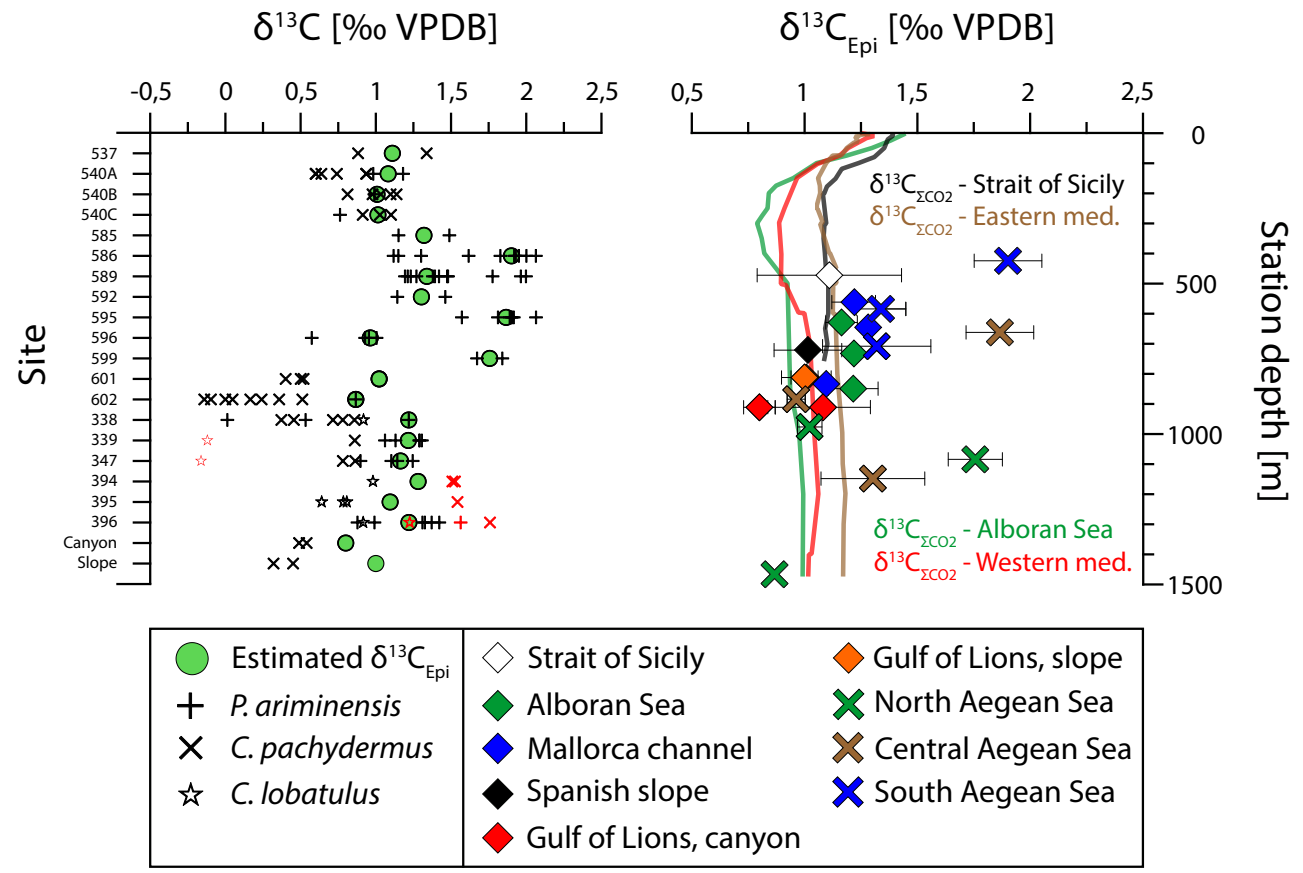

Figure 2. (a) The $\delta^{13} \mathrm{C}$ of epifaunal species (Cibicidoides pachydermus, Cibicides lobatulus, Planulina ariminensis) for each investigated site. Each symbol represents a single measurement. Red symbols mark relocated or fossil tests that have not been used to calculate $\delta^{13} \mathrm{C}_{\mathrm{Epi}}$. Green circles show $\delta^{13} \mathrm{C}_{\mathrm{Epi}}$ values used as an approximation of the $\delta^{13} \mathrm{C}$ of bottom water DIC. Details on the selection of tests and procedure for the estimation of $\delta^{13} \mathrm{C}_{\mathrm{Epi}}$ values are discussed in Sect. 4.1. (b) The $\delta^{13} \mathrm{C}_{\mathrm{Epi}}$ vs. water depth shows a wider scattering for the Aegean Sea than for the western Mediterranean Sea. Colored lines in the background indicate water mass end members of the Mediterranean Sea after Pierre (1999).

surements were performed at the Alfred Wegener Institute, Helmholtz Centre for Polar and Marine Research at Bremerhaven with two Finnigan MAT 253 stable isotope ratio mass spectrometers coupled to automatic carbonate preparation devices (Kiel IV). The mass spectrometers were calibrated via international standard NBS 19 to the PDB scale, with results given in $\delta$ notation vs. VPDB. Based on an internal laboratory standard (Solnhofen limestone) measured over a 1-year period together with samples, the precision of stable isotope measurements was better than 0.06 and $0.08 \%$ o for carbon and oxygen, respectively. The $\delta^{13} \mathrm{C}$ difference between epifaunal and shallow infaunal taxa was calculated as a proxy for the difference in $\delta^{13} \mathrm{C}$ in DIC of bottom and shallow pore water. For $U$. mediterranea, this procedure was restricted to measurements from the size fraction greater than $600 \mu \mathrm{m}$ in order to minimize ontogenetic effects (Schmiedl et al., 2004; Theodor et al., 2016).

Total organic carbon (TOC) concentration in the surface sediment was measured with a Carlo Erba 1500 CNS analyzer with a precision of $0.02 \%$ on weighted sample splits in tin capsules. Before measurement, $\mathrm{CaCO}_{3}$ was removed from these weighted samples by adding $1 \mathrm{~N} \mathrm{HCl}$. The TOC values of Sites 596, 601, and 602 were taken from Möbius et al. (2010a, b). Bottom water oxygen concentrations are based on CTD measurements stored in the MedAtlas data set. Pri- mary productivity values in surface waters of the year preceding the sampling at each site are based on satellite data of the GlobColour project, and were calculated with the algorithms of Antoine and Morel (1996) as well as Uitz et al. (2008). If available, these estimates were compared with nearby direct primary productivity and export flux measurements. The export fluxes down to the sea floor were estimated according to the function of Betzer et al. (1984) adapted by Felix (2014).

\section{Results}

Benthic foraminiferal $\delta^{13} \mathrm{C}$ values of our samples cover a range of more than $3 \%$, with higher average values of epifaunal species than shallow infaunal Uvigerina mediterranea (Table 2). The epifaunal species Cibicidoides pachydermus, Cibicides lobatulus, and Planulina ariminensis show average values between $1.90 \%$ at Site 586 (southern Aegean Sea) and $-0.16 \%$ at Site 347 (Mallorca Channel) (Table 2, Fig. 2). The highest average epifaunal $\delta^{13} \mathrm{C}_{\mathrm{Epi}}$ values are in the southern and central Aegean Sea (Sites 586, 595), while further to the north at Site 602 (northern Aegean Sea) the average $\delta^{13} \mathrm{C}_{\mathrm{Epi}}$ value of $0.87 \%$ is among the lowest measured. At Site $540 \mathrm{~B}$ in the Gulf of Lion, the average $\delta^{13} \mathrm{C}_{\mathrm{Epi}}$ value of $1.01 \%$ is in good agreement with $1.00 \%$ measured by 


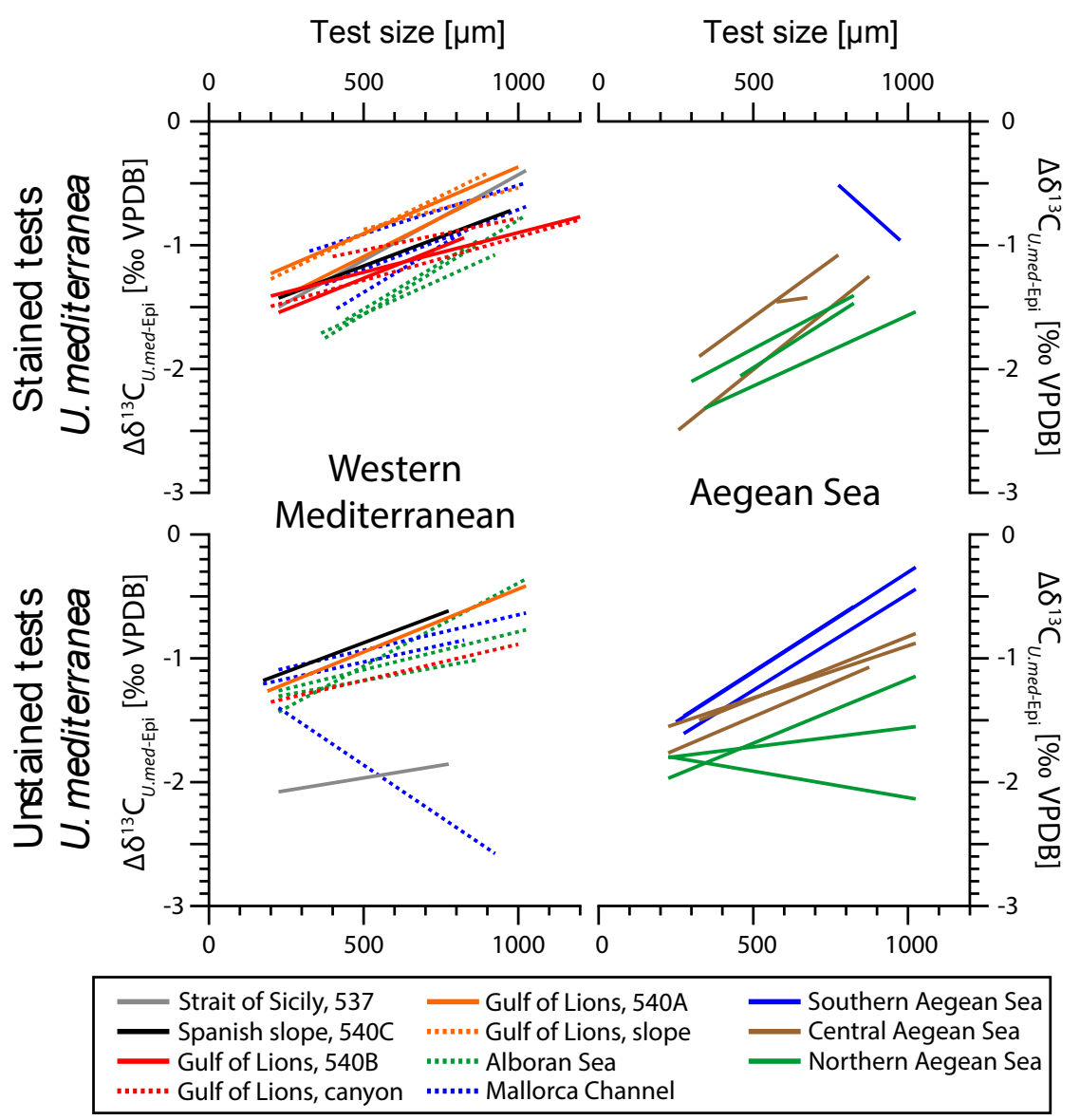

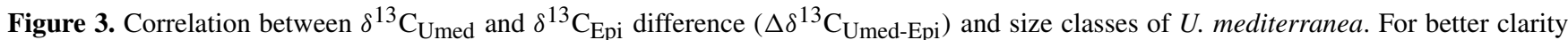
and due to the large number of measured data (Table 1), the linear regressions for each site are given, showing clear ontogenetic trends in $\delta^{13} \mathrm{C}_{\text {Umed }}$ due to size-independent $\delta^{13} \mathrm{C}_{\text {Epi }}$ values. The shown data are from live (rose-bengal-stained) and dead (unstained) individuals of $U$. mediterranea as well as for the western Mediterranean Sea (left) and Aegean Sea (right). Dashed lines represent already published data (Schmiedl et al., 2004; Theodor et al., 2016).

Schmiedl et al. (2004) at the same site. Size-dependent measurements did not reveal any ontogenetic trend in the $\delta^{13} \mathrm{C}$ signal of the epifaunal taxa (Table $\mathrm{S} 1$ in the Supplement).

For $U$. mediterranea, $\delta^{13} \mathrm{C}_{\text {Umed }}$ values vary between -1.41 and $0.85 \%$ o for stained tests and between -1.52 and $1.77 \%$ for unstained tests (Table 1). The highest average values are recorded in the southern Aegean Sea, with 0.58 and $1.11 \%$ for stained and unstained tests, respectively. The lowest average values are recorded for the northern Aegean Sea, with -0.98 and $-1.13 \%$ for stained and unstained tests, respectively. The variability at a single site reaches $1.38 \%$ in stained (Site 537) and $2.21 \%$ in unstained tests (Site 586). The ontogenetic ${ }^{13} \mathrm{C}_{\text {Umed }}$ trends are generally comparable in the western Mediterranean Sea and the Strait of Sicily, with $0.11 \pm 0.03 \% \circ 100 \mu^{-1}$ for stained and $0.07 \pm 0.03 \% 100 \mu^{-1}$ for unstained tests, except for Site 396 that shows an anomalous negative trend (Table 3, Fig. 3).
In the Aegean Sea, the ontogenetic $\delta^{13} \mathrm{C}_{\text {Umed }}$ trends are approximately $50 \%$ steeper with an increase of $0.16 \pm 0.04 \%$ o $100 \mathrm{\mu m}^{-1}$ for stained tests. Unstained tests reveal a higher variability and a less steep slope of $0.10 \pm 0.07 \%$ o $100 \mu \mathrm{m}^{-1}$ (Table 3, Fig. 3). In order to avoid bias due to ontogenetic effects, only $\delta^{13} \mathrm{C}$ values of $U$. mediterranea tests larger than $600 \mu \mathrm{m}$ were used for comparison with $\delta^{13} \mathrm{C}_{\mathrm{Epi}}$ values.

The calculated $\Delta \delta^{13} \mathrm{C}_{\text {Umed-Epi values for stained tests }}$ range from $-0.64 \%$ in the Gulf of Lion (slope site) and $-0.74 \%$ (Site 585 ) to $-1.29 \%$ in the western Mediterranean Sea (Sites 347 and 540A) to $-1.85 \%$ in the northern Aegean Sea (Site 602) (Table 2). Due to the wider scattering of the $\delta^{13} \mathrm{C}$ values of unstained tests, $\Delta \delta^{13} \mathrm{C}_{\text {Umed-Epi values }}$ range from $-0.61 \%$ (Site 589) to $-2.0 \%$ (Site 602) in the Aegean Sea and from $-0.55 \%$ (Site $540 \mathrm{~B}$ ) to $-1.06 \%$ (Site 339 ) in the western Mediterranean Sea and the Strait of Sicily (Table 2). The magnitude of $\Delta \delta^{13} \mathrm{C}_{\text {Umed-Epi }}$ values exhibits a 
Table 2. Average stable carbon isotope composition of selected benthic foraminifera with standard deviations. Bold values of epifaunal species were applied to estimate $\delta^{13} \mathrm{C}_{\mathrm{Epi}}$. Also given are values for Uvigerina mediterranea tests larger than $600 \mu \mathrm{m}$ and the difference of this species compared to the average epifaunal stable carbon isotope ratios $\left(\Delta \delta^{13} \mathrm{C}_{\text {Umed-Epi }}\right)$.

\begin{tabular}{|c|c|c|c|c|c|c|c|c|}
\hline Site & $\begin{array}{r}\delta^{13} \mathrm{C}_{\text {Pari }} \\
(\% \circ \mathrm{VPDB})\end{array}$ & $\mathrm{SD}(\% o)$ & $\begin{array}{c}\delta^{13} \mathrm{C}_{\mathrm{Cpac}} \\
(\% \text { VPDB })\end{array}$ & $\mathrm{SD}(\% o)$ & $\begin{array}{r}{ }^{{ }^{13} \mathrm{C}_{\mathrm{Clob}}} \\
(\% \text { VPDB })\end{array}$ & SD $(\% o)$ & $\begin{array}{r}\delta^{13} \mathrm{C}_{\mathrm{Epi}} \\
(\% \text { VPDB })\end{array}$ & $\mathrm{SD}(\% o)$ \\
\hline 537 & & & 1.11 & 0.32 & & & 1.11 & 0.32 \\
\hline $540 \mathrm{~A}$ & 1.08 & 0.14 & 0.76 & 0.17 & & & 1.08 & 0.14 \\
\hline $540 B$ & 0.99 & & 1.01 & 0.13 & & & 1.01 & 0.11 \\
\hline $540 \mathrm{C}$ & 0.76 & & 1.01 & 0.09 & & & 1.01 & 0.09 \\
\hline 585 & 1.32 & 0.24 & & & & & 1.32 & 0.24 \\
\hline 586 & 1.90 & 0.15 & & & & & 1.90 & 0.15 \\
\hline 589 & 1.34 & 0.11 & & & & & 1.34 & 0.11 \\
\hline 592 & 1.30 & 0.23 & & & & & 1.30 & 0.23 \\
\hline 595 & 1.87 & 0.15 & & & & & 1.87 & 0.15 \\
\hline 596 & 0.96 & 0.04 & & & & & 0.96 & 0.04 \\
\hline 599 & 1.76 & 0.12 & & & & & 1.76 & 0.12 \\
\hline 601 & & & 0.47 & 0.06 & & & 1.02 & 0.06 \\
\hline 602 & 0.87 & & 0.31 & 0.20 & & & 0.87 & \\
\hline 338 & 1.22 & & 0.64 & 0.21 & 0.92 & & 1.22 & \\
\hline 339 & 1.22 & 0.11 & 0.86 & & -0.12 & & 1.22 & 0.11 \\
\hline 347 & 1.16 & 0.07 & 0.82 & 0.06 & -0.16 & & 1.16 & 0.07 \\
\hline 394 & & & 1.52 & 0.01 & 0.98 & & 1.28 & \\
\hline 395 & & & 1.54 & & 0.80 & 0.02 & 1.1 & 0.02 \\
\hline 396 & 1.22 & 0.22 & 1.76 & & 0.92 & & 1.22 & 0.22 \\
\hline Canyon $\varnothing$ & & & 0.52 & 0.04 & & & 0.80 & 0.07 \\
\hline Slope $\varnothing$ & & & 0.39 & 0.09 & & & 1.00 & 0.06 \\
\hline
\end{tabular}

Table 2. Continued.

\begin{tabular}{|c|c|c|c|c|c|c|c|c|c|c|c|c|}
\hline Site & $\begin{array}{r}\delta^{13} \mathrm{C}_{\text {Umed }} \\
\text { stained } \\
(\% \circ \mathrm{VPDB})\end{array}$ & $\mathrm{SD}(\% o)$ & $\begin{array}{l}\delta^{13} \mathrm{C}_{\text {Umed }} \\
\text { unstained } \\
(\% \circ \mathrm{VPDB})\end{array}$ & $\mathrm{SD}(\% o)$ & $\begin{array}{r}\delta^{13} \mathrm{C}_{\text {Umed }} \\
\text { stained } \\
(>600 \mu \mathrm{m}) \\
(\% \text { VPDB })\end{array}$ & $\mathrm{SD}(\% \circ)$ & $\begin{array}{r}{ }^{13} \mathrm{C}_{\text {Umed }} \\
\text { unstained } \\
(>600 \mu \mathrm{m}) \\
(\% \text { VPDB })\end{array}$ & $\mathrm{SD}(\% o)$ & $\begin{array}{r}\Delta \delta^{13} \mathrm{C}_{\text {Umed-Epi }} \\
\text { stained } \\
(>600 \mu \mathrm{m}) \\
(\% o)\end{array}$ & $\mathrm{SD}(\% o)$ & $\begin{array}{r}\Delta \delta^{13} \mathrm{C}_{\text {Umed-Epi }} \\
\text { unstained } \\
(>600 \mu \mathrm{m}) \\
(\% o)\end{array}$ & $\mathrm{SD}(\% 0)$ \\
\hline 537 & 0.17 & 0.38 & -0.88 & 0.16 & 0.35 & 0.26 & -0.82 & 0.03 & -0.76 & 0.58 & -1.93 & 0.35 \\
\hline $540 \mathrm{~A}$ & -0.46 & 0.21 & & & -0.21 & 0.09 & & & -1.29 & 0.30 & & \\
\hline $540 \mathrm{~B}$ & 0.13 & 0.32 & 0.19 & 0.35 & 0.27 & 0.23 & 0.46 & 0.10 & -0.74 & 0.34 & -0.55 & 0.21 \\
\hline $540 \mathrm{C}$ & -0.14 & 0.30 & 0.06 & 0.32 & 0.05 & 0.26 & 0.28 & 0.32 & -0.97 & 0.41 & -0.74 & 0.47 \\
\hline 585 & 0.58 & 0.22 & 0.50 & 0.47 & 0.58 & 0.22 & 0.50 & 0.22 & -0.74 & 0.46 & -0.82 & 0.46 \\
\hline 586 & & & 0.95 & 0.46 & & & 1.11 & 0.31 & & & -0.79 & 0.46 \\
\hline 589 & & & 0.51 & 0.46 & & & 0.73 & 0.39 & & & -0.61 & 0.50 \\
\hline 592 & -0.14 & 0.02 & 0.15 & 0.25 & -0.12 & 0.00 & 0.24 & 0.20 & -1.42 & 0.23 & -1.06 & 0.43 \\
\hline 595 & 0.09 & 0.53 & 0.67 & 0.41 & 0.37 & 0.31 & 0.77 & 0.41 & -1.49 & 0.46 & -1.09 & 0.56 \\
\hline 596 & -0.38 & 0.38 & -0.43 & 0.34 & -0.23 & 0.33 & -0.27 & 0.27 & -1.19 & 0.37 & -1.23 & 0.31 \\
\hline 599 & 0.03 & 0.26 & 0.25 & 0.45 & 0.12 & 0.20 & 0.41 & 0.28 & -1.63 & 0.32 & -1.35 & 0.40 \\
\hline 601 & -0.53 & 0.27 & -0.47 & 0.38 & -0.34 & 0.14 & -0.37 & 0.35 & -1.36 & 0.20 & -1.39 & 0.41 \\
\hline 602 & -1.11 & 0.31 & -1.09 & 0.27 & -0.98 & 0.32 & -1.13 & 0.26 & -1.85 & 0.32 & -2.00 & 0.26 \\
\hline 338 & -0.05 & 0.26 & 0.29 & 0.37 & 0.07 & 0.28 & 0.55 & 0.23 & -1.15 & 0.28 & -0.67 & 0.23 \\
\hline 339 & 0.02 & 0.46 & 0.06 & 0.20 & 0.22 & 0.28 & 0.16 & 0.19 & -0.99 & 0.39 & -1.06 & 0.30 \\
\hline 347 & -0.19 & 0.25 & 0.02 & 0.17 & -0.13 & 0.13 & 0.41 & 0.00 & -1.29 & 0.20 & -0.75 & 0.07 \\
\hline 394 & 0.58 & 0.31 & 0.61 & 0.23 & 0.64 & 0.26 & 0.71 & 0.13 & -0.64 & 0.27 & -0.58 & 0.14 \\
\hline 395 & 0.47 & 0.30 & 0.53 & 0.21 & 0.53 & 0.27 & 0.63 & 0.13 & -0.57 & 0.27 & -0.46 & 0.13 \\
\hline 396 & 0.66 & 0.22 & -0.64 & 0.60 & 0.72 & 0.19 & -0.91 & 0.42 & -0.50 & 0.29 & -2.13 & 0.52 \\
\hline Canyon $\varnothing$ & -0.32 & 0.29 & -0.32 & 0.27 & -0.17 & 0.20 & -0.21 & 0.26 & -0.97 & 0.27 & -1.01 & 0.33 \\
\hline Slope $\varnothing$ & 0.26 & 0.30 & & & 0.33 & 0.26 & & & -0.67 & 0.32 & & \\
\hline
\end{tabular}

relation with trophic conditions at each site, revealing higher values at more eutrophic sites.

The median living depth of the shallow infaunal $U$. mediterranea (MLD Umed ) is used here to describe its microhabitat and generally increases at sites with deep main re- dox boundaries, at least in the western Mediterranean Sea. The deepest MLD Umed are 2.13 and $2.25 \mathrm{~cm}$ in the southern Aegean Sea, while the shallowest depths of 0.27 and $0.38 \mathrm{~cm}$ are recorded in the central and northern Aegean Sea, respectively (Table 1). In the Gulf of Lion, the MLD Umed is between 


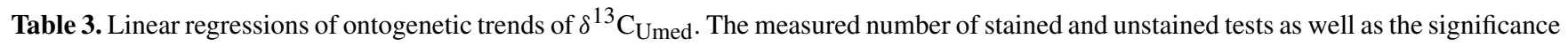
values are added.

\begin{tabular}{|c|c|c|c|c|}
\hline \multicolumn{5}{|c|}{ U. mediterranea stained } \\
\hline Site & $n$ & Linear fit & $R^{2}$ & $p$ value \\
\hline 537 & 24 & $Y=0.001379 \times X-1.810017$ & 0.67 & $1.1065 \times 10 e^{-6}$ \\
\hline $540 \mathrm{~A}$ & 23 & $Y=0.001007 \times X-1.770373$ & 0.70 & $5.746 \times 10 e^{-7}$ \\
\hline $540 \mathrm{~B}$ & 14 & $Y=0.001257 \times X-1.7208851$ & 0.54 & 0.0027 \\
\hline $540 \mathrm{C}$ & 46 & $Y=0.000943 \times X-1.639236$ & 0.55 & $3.769 \times 10 e^{-6}$ \\
\hline 585 & 3 & $Y=-0.00224 \times X+1.222667$ & 1.00 & 0.0082 \\
\hline 592 & 2 & $Y=0.00034 \times X-1.6535$ & 1.00 & $\mathrm{n} / \mathrm{a}$ \\
\hline 595 & 10 & $Y=0.002013 \times X-3.012139$ & 0.75 & 0.0012 \\
\hline 596 & 7 & $Y=0.001822 \times X-2.490764$ & 0.60 & 0.0401 \\
\hline 599 & 10 & $Y=0.001600 \times X-2.789560$ & 0.49 & 0.0289 \\
\hline 601 & 11 & $Y=0.001322 \times X-2.497314$ & 0.70 & 0.0013 \\
\hline 602 & 15 & $Y=0.001143 \times X-2.709099$ & 0.41 & 0.0102 \\
\hline 338 & 10 & $Y=0.001498 \times X-2.265059$ & 0.72 & 0.0020 \\
\hline 339 & 12 & $Y=0.001527 \times X-2.323114$ & 0.48 & 0.0124 \\
\hline 347 & 7 & $Y=0.001126 \times X-2.119201$ & 0.68 & 0.0232 \\
\hline 394 & 19 & $Y=0.000968 \times X-1.680654$ & 0.27 & 0.0221 \\
\hline 395 & 23 & $Y=0.001509 \times X-2.135640$ & 0.40 & 0.0012 \\
\hline 396 & 20 & $Y=0.000789 \times X-1.304866$ & 0.39 & 0.0034 \\
\hline Canyon aug & 7 & $Y=0.000516 \times X-1.297794$ & 0.45 & 0.1015 \\
\hline Canyon (Feb) & 21 & $Y=0.000701 \times X-1.634263$ & 0.43 & 0.0012 \\
\hline Slope (Aug) & 6 & $Y=0.000671 \times X-1.207976$ & 0.34 & 0.2244 \\
\hline Slope (Feb) & 14 & $Y=0.001223 \times X-1.518849$ & 0.48 & 0.0060 \\
\hline \multicolumn{5}{|c|}{ U. mediterranea unstained } \\
\hline Site & $n$ & Linear fit & $R^{2}$ & $p$ value \\
\hline 537 & 7 & $Y=0.000408 \times X-2.169793$ & 0.33 & 0.1784 \\
\hline $540 \mathrm{~B}$ & 16 & $Y=0.001017 \times X-1.457536$ & 0.80 & $2.4803 \times 10 e^{-6}$ \\
\hline $540 \mathrm{C}$ & 9 & $Y=0.000938 \times X-1.343878$ & 0.53 & 0.0270 \\
\hline 585 & 4 & $Y=0.001610 \times X-1.910093$ & 0.85 & 0.0808 \\
\hline 586 & 29 & $Y=0.001555 \times X-2.035859$ & 0.48 & $2.9156 \times 10 e^{-5}$ \\
\hline 589 & 25 & $Y=0.001612 \times X-1.917381$ & 0.58 & $1.0482 \times 10 e^{-5}$ \\
\hline 592 & 28 & $Y=0.001001 \times X-1.826222$ & 0.48 & $4.5201 \times 10 e^{-5}$ \\
\hline 595 & 36 & $Y=0.000841 \times X-1.740275$ & 0.17 & 0.0130 \\
\hline 596 & 37 & $Y=0.001065 \times X-2.004262$ & 0.30 & 0.0005 \\
\hline 599 & 12 & $Y=0.001031 \times X-2.201211$ & 0.31 & 0.0600 \\
\hline 601 & 21 & $Y=0.000312 \times X-1.871316$ & 0.04 & 0.3927 \\
\hline 602 & 14 & $Y=-0.000427 \times X-1.697763$ & 0.12 & 0.2159 \\
\hline 338 & 10 & $Y=0.001343 \times X-1.735480$ & 0.90 & $3.0586 \times 10 e^{-5}$ \\
\hline 339 & 9 & $Y=0.000456 \times X-1.408000$ & 0.31 & 0.1197 \\
\hline 347 & 10 & $Y=0.000615 \times X-1.400530$ & 0.71 & 0.0023 \\
\hline 394 & 22 & $Y=0.000573 \times X-1.221329$ & 0.32 & 0.0060 \\
\hline 395 & 15 & $Y=0.000544 \times X-1.301955$ & 0.33 & 0.0256 \\
\hline 396 & 17 & $Y=-0.001682 \times X-1.020989$ & 0.50 & 0.0016 \\
\hline Canyon (Aug) & 36 & $Y=0.000584 \times X-1.469912$ & 0.28 & 0.0009 \\
\hline
\end{tabular}

0.43 and $0.49 \mathrm{~cm}$ in the axis of the Lacaze-Duthiers Canyon and around $1.22 \mathrm{~cm}$ on the open slope (Table 1, Fig. 4a). The depth of the sediment color change, which marks the shift in redox potential and thus oxygen penetration, ranges from $2.25 \mathrm{~cm}$ in the Gulf of Lion (Site 540A) to as much as $30 \mathrm{~cm}$ in the central Aegean Sea (Site 596) (Table 1, Fig. 4b).
The measured TOC contents of the surface sediment range from $0.41 \%$ (Site 586, southern Aegean Sea) and $0.58 \%$ (Site 537, Strait of Sicily) to a maximum of $0.82 \%$ (Site 602, northern Aegean Sea) (Table 1, Fig. 4c). The $\Delta \delta^{13} \mathrm{C}_{\text {Umed-Epi }}$

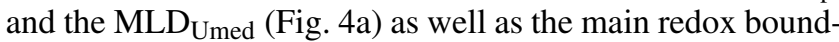




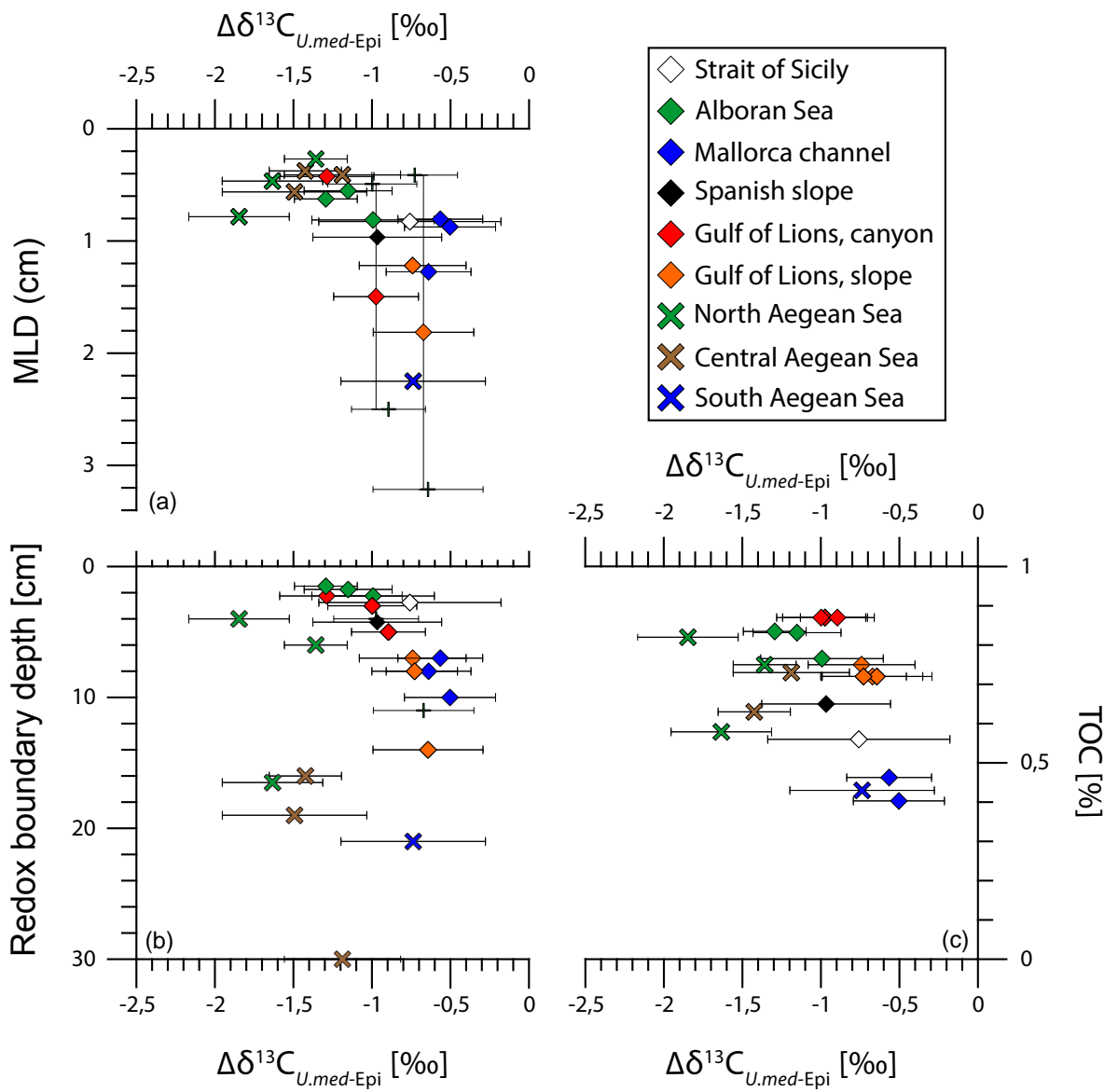

Figure 4. The $\delta^{13} \mathrm{C}$ difference between live Uvigerina mediterranea and epifaunal taxa $\left(\Delta \delta^{13} \mathrm{C}_{\text {Umed-Epi }}\right)$ plotted against (a) MLD of $U$. mediterranea, (b) depth of redox boundary in the sediment, and (c) TOC content of the sediment. The MLD error bars for the canyon and slope sites in the Gulf of Lion reflect the seasonal MLD contrasts of U. mediterranea between February and August 1997 (Schmiedl et al., 2004).

ary depth (Fig. 4b) show good correspondence, whereas the link to percentage of TOC is less distinct (Fig. 4c).

The estimated values for annual primary production (PP) range from 106 to $294 \mathrm{~g} \mathrm{C} \mathrm{m}^{-2} \mathrm{a}^{-1}$. Application of the different algorithms of Antoine and Morel (1996) and Uitz et al. (2008) resulted in an average offset of $54 \mathrm{~g} \mathrm{C} \mathrm{m}^{-2} \mathrm{a}^{-1}$, with PP values consistently higher when applying the algorithm of Antoine and Morel (1996). The highest PP values occur in the Alboran Sea (274-294 vs. 192-207 g C m ${ }^{-2} \mathrm{a}^{-1}$ according to Uitz et al., 2008) and the northern Aegean Sea (196-237 and 139-164 $\mathrm{g} \mathrm{C} \mathrm{m}^{-2} \mathrm{a}^{-1}$, respectively), while the lowest PP values occur in the southern and central Aegean Sea (151-161 and 106-116 $\mathrm{g} \mathrm{C} \mathrm{m}^{-2} \mathrm{a}^{-1}$, respectively) (Table 1).

\section{Discussion}

\subsection{Stable carbon isotope signal of epifaunal foraminifera in relation to surrounding water masses}

The $\delta^{13} \mathrm{C}$ of Cibicidoides pachydermus, Cibicides lobatulus, and Planulina ariminensis seems to reflect the $\delta^{13} \mathrm{C}_{\mathrm{DIC}}$ of the ambient bottom water since these species prefer an epifaunal microhabitat (Lutze and Thiel, 1989; Kitazato, 1994; Schmiedl et al., 2000). Comparison with published water $\delta^{13} \mathrm{C}_{\mathrm{DIC}}$ measurements confirms that $\delta^{13} \mathrm{C}_{\mathrm{Epi}}$ values are a possible bottom water proxy for the Mediterranean Sea (Pierre, 1999; Schmiedl et al., 2004; Theodor et al., 2016). Further, our new data corroborate previous observations that ontogenetic effects in the $\delta^{13} \mathrm{C}_{\mathrm{Epi}}$ signal of these taxa are lacking (Corliss et al., 2002; Franco-Fraguas et al., 2011; Theodor et al., 2016) (Table S1).

Because of the lack of stained epifaunal tests at most sites, unstained tests were integrated into the analysis. For empty 
tests, a shift to higher $\delta^{13} \mathrm{C}_{\mathrm{Epi}}$ values due to potential dissolution effects should be considered (Edgar et al., 2013). In addition, reworked or allochthonous tests can bias the results as documented for the $\delta^{13} \mathrm{C}_{\text {Cpachy }}$ of Site 396 in the Mallorca Channel. At this site, fossil tests have been admixed in the surface sediment as indicated by heavy $\delta^{18} \mathrm{O}$ values of greater than $4.0 \%$ (Table S1). In the Alboran Sea (Sites 339 and 347), we measured interspecific epifaunal $\delta^{13} \mathrm{C}$ differences of up to $1.4 \%$. This variability is a result of implausibly low $\delta^{13} \mathrm{C}_{\text {Clob }}$ values, probably due to a relocation from shallower depths closer to the coast. These unrealistic $\delta^{13} \mathrm{C}_{\mathrm{Cpachy}}$ and $\delta^{13} \mathrm{C}_{\mathrm{Clob}}$ values were omitted for $\delta^{13} \mathrm{C}_{\mathrm{Epi}}$ estimation. In order to minimize these biases, a large number of tests were measured, which was possible for $C$. pachydermus and $P$. ariminensis, showing commonly $0.3-0.5 \%$ o higher $\delta^{13} \mathrm{C}$ values for the latter species (Table 2, Fig. 2a). Despite the aforementioned uncertainties, data of $C$. lobatulus were used to estimate $\delta^{13} \mathrm{C}_{\mathrm{Epi}}$ at the Mallorca Channel Sites 394 and 395 , when no tests of other species were available for analysis (Theodor et al., 2016). For proper $\delta^{13} \mathrm{C}_{\mathrm{Epi}}$ estimation of Sites 394 and 395, the difference between $\delta^{13} \mathrm{C}_{\text {Pari }}$ and $\delta^{13} \mathrm{C}_{\mathrm{Clob}}\left(\Delta \delta^{13} \mathrm{C}_{\text {Pari-Clob }}=0.30 \%\right.$ ) at Site 396 was added to

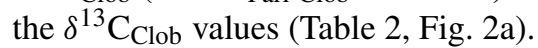

The $\delta^{13} \mathrm{C}$ offset between C. pachydermus and P. ariminensis is not constant and appears to increase at sites with deep main redox boundaries. This suggests a connection with increasing organic matter availability and the varying offsets can be attributed to slight differences in their microhabitat (Table 2, Fig. 2a). While $P$. ariminensis is a strictly epifaunal species, living attached on surfaces or above the sediment (Lutze and Thiel, 1989), C. pachydermus commonly lives at or slightly below the sediment-water interface (Rathburn and Corliss, 1994; Schmiedl et al., 2000; Licari and Mackensen, 2005). A very shallow infaunal microhabitat of C. pachydermus is corroborated by slightly lower $\delta^{13} \mathrm{C}$ values relative to bottom water $\delta^{13} \mathrm{C}_{\text {DIC }}$ suggesting pore water influence (Schmiedl et al., 2004; Fontanier et al., 2006). In order to compensate for potential pore water effects in the $\delta^{13} \mathrm{C}$ signal of the epifaunal species, the highest $\delta^{13} \mathrm{C}_{\mathrm{Epi}}$ values, mostly of $P$. ariminensis, should be selected for further comparison with shallow infaunal $\delta^{13} \mathrm{C}_{\text {Umed }}$ signals. This strategy could not always be realized, either due to the lack of P. ariminensis (Sites 537, 601, canyon, and slope) or when lower $\delta^{13} \mathrm{C}$ values were recorded for $P$. ariminensis relative to $C$. pachydermus (Site 540C). In these cases, bottom water $\delta^{13} \mathrm{C}_{\text {DIC }}$ measurements (canyon, slope; data from Schmiedl et al., 2004), the addition of the $\Delta \delta^{13} \mathrm{C}_{\text {Pari-Cpachy value of the }}$ nearby Site 602 (for correction of Site 601) or the $\delta^{13} C_{\text {Cpachy }}$ values (Sites 537, 540C) were used, accepting possible deviations of $\delta^{13} \mathrm{C}_{\mathrm{Epi}}$ from bottom water $\delta^{13} \mathrm{C}_{\text {DIC }}$ (Table 2).

The applied $\delta^{13} \mathrm{C}_{\mathrm{Epi}}$ values are related to different Mediterranean water masses (Fig. 2b). The $\delta^{13} \mathrm{C}_{\text {Epi values }}$ of the Gulf of Lion and the Spanish continental slope off Barcelona are around $1.0 \%$ matching the $\delta^{13} \mathrm{C}_{\mathrm{DIC}}$ signature of upper western Mediterranean deep water (WMDW)
(Pierre, 1999). Likewise, the slightly higher $\delta^{13} \mathrm{C}_{\mathrm{Epi}}$ values of $1.1 \%$ in the Strait of Sicily fall in the range of $\delta^{13} \mathrm{C}_{\text {DIC }}$ values of intermediate waters from the eastern Mediterranean Sea and reflect the transitional setting of this area. In contrast, the $\delta^{13} C_{\mathrm{Epi}}$ values of the Mallorca Channel and the Alboran Sea are even higher than those recorded for the eastern Mediterranean Sea (Fig. 2b). This inconsistent isotope pattern likely reflects a shift in deep-water formation in the eastern Mediterranean during the 1990s, the so-called Eastern Mediterranean Transient (EMT; Roether et al., 2007). The EMT was accompanied by an enhanced deep-water formation in the Aegean Sea and also fostered a complete renewal of WMDW during the mid-2000s (Schroeder et al., 2006, 2008). Unfortunately, the imprint of WMDW change on $\delta^{13} \mathrm{C}_{\text {DIC }}$ of the water mass was not documented, but it should have affected the sites sampled after this transition, i.e., during Meteor cruise M69/1 in 2006.

The broad range of recorded $\delta^{13} \mathrm{C}_{\mathrm{Epi}}$ values of 0.87 to $1.95 \%$ in the Aegean Sea reflects the strong small-scale oceanographic differences of this region, including presence of various small isolated basins (Figs. 1, 2b). The comparatively high $\delta^{13} \mathrm{C}_{\mathrm{Epi}}$ values of the shallower sites indicate intensified vertical convection at sites of subsurface water formation, which recently resumed after the stagnation phase of 1994-2000 (Androulidakis et al., 2012), although the main deep-water formation area is restricted to the Cretan Sea (Roether et al., 1996; Lascaratos et al., 1999). Reduced replenishment of bottom waters at greater depth of isolated basins (Zervakis et al., 2003; Velaoras and Lascaratos, 2005) is accompanied by relatively low $\delta^{13} \mathrm{C}_{\mathrm{DIC}}$ and accordingly low $\delta^{13} \mathrm{C}_{\mathrm{Epi}}$ values in these environments.

\subsection{Biological and environmental effects on the stable carbon isotope signal of Uvigerina mediterranea}

Size-dependent changes in the $\delta^{13} \mathrm{C}$ signal of Uvigerina mediterranea are attributed to ontogenetic effects. Small tests are depleted in ${ }^{13} \mathrm{C}$, while larger tests are closer to $\delta^{13} \mathrm{C}_{\mathrm{DIC}}$ of the ambient pore water (Fig. 3). Relatively low $\delta^{13} \mathrm{C}_{\text {Umed }}$ values of small tests suggest stronger metabolic fractionation in younger individuals (Schmiedl et al., 2004; McCorkle et al., 2008; Schumacher et al., 2010; Theodor et al., 2016). A linear ontogenetic increase of $0.11 \% \circ 100 \mu^{-1}$ was observed at all sites of the western Mediterranean Sea, while a steeper slope of $0.16 \% \circ 100 \mu \mathrm{m}^{-1}$ was recorded in the Aegean Sea (Fig. 3). In addition, the $\delta^{13} \mathrm{C}_{\text {Umed }}$ values of small individuals from the Aegean Sea were of order 1\%o lower compared to those from the western Mediterranean Sea.

Differences in ontogenetic $\delta^{13} \mathrm{C}$ slopes of the related species $U$. peregrina have been attributed to its highly opportunistic response to regional contrasts in organic matter quantity and quality, and seasonality of supply (Theodor et al., 2016). Obviously, similar effects are also operational in ontogenetic $\delta^{13} \mathrm{C}$ trends of $U$. mediterranea. In the Aegean Sea, this species appears to respond to strong seasonal contrasts 
in organic matter fluxes (Siokou-Frangou et al., 2002) resulting in particularly high metabolic activity and low $\delta^{13} \mathrm{C}_{\text {Umed }}$ values in young individuals. A steepening of the $\delta^{13} \mathrm{C}_{\text {Umed }}$ slopes from the north to the south Aegean Sea probably occurs for the same reasons as $U$. peregrina in the western Mediterranean Sea. Because of the higher number of measured tests, this shift of the slope angles is more obvious in unstained than stained tests (Fig. 3). Although the number of sites was larger than in Theodor et al. (2016), a similar trend in $\delta^{13} \mathrm{C}_{\text {Umed }}$ is not recognizable for the western Mediterranean Sea. This may express lower differences in the seasonal food supply between the sites or the total higher input of organic matter compared to the Aegean Sea.

The $\delta^{13} \mathrm{C}_{\text {Umed }}$ of unstained individuals from $5 \mathrm{~cm}$ sediment depth in the western Mediterranean Sea and Strait of Sicily are on average 0.1 to $0.2 \%$ lower than those of stained specimens in the topmost centimeter. This adds to previous observations of Theodor et al. (2016) suggesting the influence of the Suess effect (Keeling, 1979; Quay et al., 1992) in living individuals while it is absent in some 100-year-old specimens. The Suess effect reduces $\delta^{13} \mathrm{C}$ values in the atmosphere and oceans due to the anthropogenic release of isotopically light $\mathrm{CO}_{2}$ out of fossil fuels. A similar effect was not seen in the Aegean Sea since live and dead individuals were selected from the same sediment depth and thus had only minor age differences (Table 2, Fig. 3). The only exception is Site 595 in the central Aegean Sea, where the deviation is even higher $(0.5-0.7 \%$ ) when compared to the western Mediterranean Sea. Since this signal is restricted to only one site, it is probably due to relocation of fossil tests by the effects of bioturbation or lateral sediment transport.

Under well-oxygenated conditions, the pore water $\delta^{13} \mathrm{C}_{\mathrm{DIC}}$ gradient depends on the organic matter fluxes and associated decomposition rates of organic matter in the surface sediment (McCorkle and Emerson, 1988; McCorkle et al., 1985, 1990; Holsten et al., 2004). Organic matter fluxes also control the depth of the oxygenated layer (Rutgers van der Loeff, 1990) and thus the microhabitat range of infaunal foraminifera (Corliss, 1985; Jorissen et al., 1995; Koho et al., 2008; Koho and Pina-Ochoa, 2012). Subsurface waters in the Mediterranean Sea are well ventilated resulting in bottom water oxygen concentrations above $4.1 \mathrm{~mL} \mathrm{~L}^{-1}$ at all sites in our study (MedAtlas, 1997). The $\delta^{13} \mathrm{C}$ signal of $U$. mediterranea appears particularly suitable to monitor the pore water $\delta^{13} \mathrm{C}_{\text {DIC }}$ signal in the near-surface sediment because it seems to be less influenced by species-specific vital effects (McConnaughy, 1989a, b) when compared to other shallow infaunal taxa (for example, U. peregrina) (Schmiedl et al., 2004; Theodor et al., 2016).

In this study, the deviation of $\delta^{13} \mathrm{C}_{\text {Umed }}$ from bottom water $\delta^{13} \mathrm{C}_{\text {DIC }}$ (reflected as higher $\Delta \delta^{13} \mathrm{C}_{\text {Umed-Epi values; Fig. 4) }}$ suggests exponential relations with the MLD of U. mediterranea, the depth of the oxygenated layer, and the TOC content of the surface sediment. At the more oligotrophic to mesotrophic sites of the Mallorca Channel, the Gulf of Lion, the Spanish slope off Barcelona, and the southern Aegean Sea, relatively low $\Delta \delta^{13} \mathrm{C}_{\text {Umed-Epi values correspond to a rel- }}$ atively thick oxygenated layer and low TOC contents. The rather deep position of the redox boundary, exceeding $10 \mathrm{~cm}$ at some sites, enables $U$. mediterranea to inhabit a relatively wide microhabitat range. In contrast, relatively high $\Delta \delta^{13} \mathrm{C}_{\text {Umed-Epi }}$ values at the more mesotrophic to eutrophic sites of the Alboran Sea coincide with relatively thin oxygenated layers and higher TOC contents. Here, the microhabitat range of $U$. mediterranea is compressed because of limited pore water oxygen (Fig. 4).

When comparing sites within the central and northern Aegean Sea, the foraminiferal stable isotope difference and the biogeochemical and ecological characteristics lack a consistent relation (Fig. 4). In these areas, strongly negative $\Delta \delta^{13} \mathrm{C}_{\text {Umed-Epi }}$ values do not systematically correspond to maximum TOC contents and the shallowest redox boundary (Fig. 4). The reasons for this absence of a clear relation between $\Delta \delta^{13} \mathrm{C}_{\text {Umed-Epi }}$ and environmental parameters within this area cannot be unraveled with our data. It may be related to the high variability in oceanographic and biogeochemical conditions of the bottom water in the isolated basins that are characterized by focusing of organic-rich sedimentary material (Lykousis et al., 2002; Giresse et al., 2003; Poulos, 2009) and/or temporarily intermittent replenishment of deep waters on seasonal to decadal timescales (Zervakis et al., 2003; Velaoras and Lascaratos, 2005; Androulidakis et al., 2012). The first possibility can increase the supply of refractory $\mathrm{C}_{\mathrm{org}}$, recorded by higher TOC contents, and influence the foraminiferal microhabitat depths, but has minor effects on the $\delta^{13} \mathrm{C}_{\text {DIC }}$ pore water gradient. Latter possibility refers to local ventilation events, which exchange aged bottom water with comparatively low $\delta^{13} \mathrm{C}_{\text {DIC }}$ signature by surface waters enhanced in ${ }^{13} \mathrm{C}_{\text {DIC }}$. This may also push the pore water gradient towards stronger differences, explaining the more negative $\Delta \delta^{13} \mathrm{C}_{\text {Umed-Epi values, compared to the re- }}$ maining sites with similar conditions (Fig. 4).

\subsection{Development of a stable carbon-isotope-based transfer function for organic carbon fluxes}

Our results suggest a close relationship between the $\delta^{13} \mathrm{C}$ gradient in pore waters of the surface sediment (expressed as $\Delta \delta^{13} \mathrm{C}_{\text {Umed-Epi }}$ ) and the OM fluxes to the sea floor, for open-ocean settings of the western and central Mediterranean Sea and the southern Aegean Sea (Fig. 5). Based on these observations, we tested the potential for the development of a $\delta^{13} \mathrm{C}$-based transfer function for OM flux rates. In openocean settings, the main food source of deep-sea environments is the exported OM from the surface layer, where photosynthetic PP takes place (e.g., Boyd and Trull, 2007; Bishop, 2009). The majority of produced particulate organic carbon (POC) is recycled within the photic zone. In the open Mediterranean Sea, around $4 \%$ of the POC is exported out of the photic zone, which is lower than for other open oceans, 


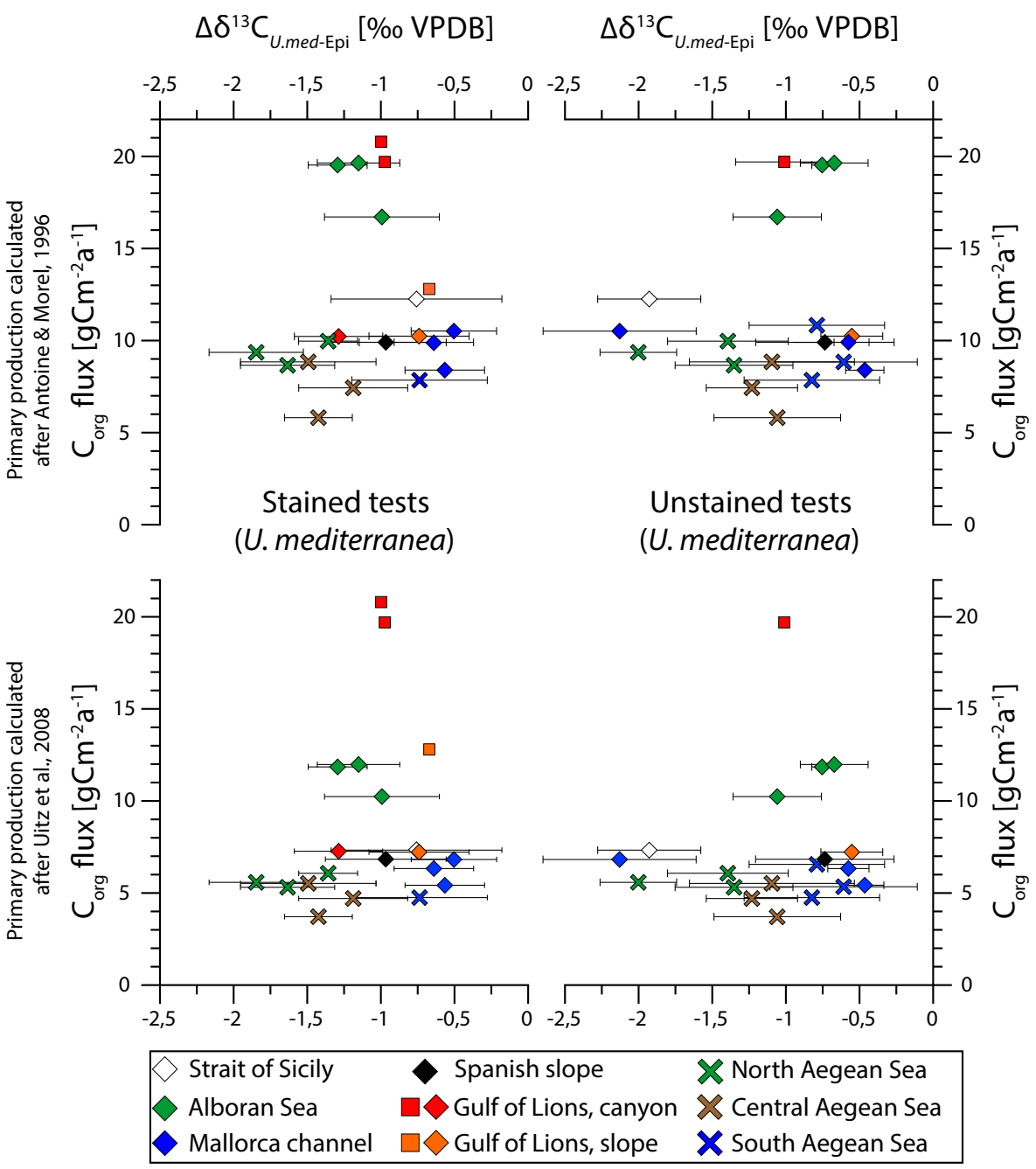

Figure 5. The $\delta^{13} \mathrm{C}$ difference between live and dead Uvigerina mediterranea and epifaunal taxa $\left(\Delta \delta^{13} \mathrm{C}_{\mathrm{Umed}-\mathrm{Epi}}\right)$ against organic carbon flux rates $\left(\mathrm{C}_{\text {org }}\right.$ flux $)$ calculated from primary productivity in surface waters after Betzer et al. (1984). As in Fig. 4, satellite-derived primary production values of Antoine and Morel (1996) (top) and Uitz et al. (2008) (bottom) were used.

caused by a specific nutrient distribution in the Mediterranean Sea (Moutin and Raimbault, 2002; Gogou et al., 2014). The remineralization of organic matter is intensified, which leads to reduced fluxes to the sea floor.

During transfer from the surface ocean to the deep sea, the amount of exported OM decreases exponentially reflecting microbial decay (Suess, 1980; de la Rocha and Passow, 2007; Packard and Gomez, 2013). Various functions have been developed for the estimation of OM fluxes during sinking of particles through the water column integrating numerous observational data (Suess, 1980; Betzer et al., 1984; Martin et al., 1987; Antia, et al., 2001). The different functions reveal a high variability for the active surface layer, while the results for deeper parts of the water column are within a comparable range (Felix, 2014). In our study (Table 1, Fig. 5), we applied the function of Betzer et al. (1984) for calculating the depthdependent $\mathrm{C}_{\text {org }}$ fluxes at the different Mediterranean sites us- ing satellite-derived PP data (Antoine and Morel, 1996; Uitz et al., 2008).

A comparison with direct PP and export flux measurements of sediment trap studies revealed ambiguous results. The PP values calculated after Antoine and Morel (1996) are in a comparable range to PP measurements in the western Mediterranean (Moutin and Raimbault, 2002; SanchezVidal et al., 2004, 2005; Zúñiga et al., 2007, 2008). However, the estimated export fluxes are too high in these areas compared to direct measurements of the referred studies, probably due to the aforementioned high remineralization rate in the Mediterranean Sea. However, the discrepancy in export fluxes is partly compensated by the application of the 21$30 \%$ lower PP values calculated after Uitz et al. (2008). For the Aegean Sea, in contrast, distinctively higher measured PP values have been reported than were estimated (SiokouFrangou et al., 2002). For the Gulf of Lion, measured OM 
export fluxes exceed the predicted values (Heussner et al., 2006), which can be explained by the additional lateral input of organic carbon channeled within the local canyon systems (Schmiedl et al., 2000). In order to compensate for these possible additional $\mathrm{C}_{\text {org }}$ fluxes in marginal basin areas, the application of the function of Antoine and Morel (1996) is more promising; hence, a potential overestimation of $\mathrm{C}_{\text {org }}$ fluxes in open-ocean areas has to be considered.

For both approaches of PP calculation (Antoine and Morel, 1996; Uitz et al., 2008), the relation between the estimated $\mathrm{C}_{\text {org }}$ fluxes and the $\Delta \delta{ }^{13} \mathrm{C}_{\text {Umed-Epi }}$ exhibits a complex pattern and, at first instance, lacks a simple and statistically significant correlation (Fig. 5). Particularly, strongly negative $\Delta \delta^{13} \mathrm{C}_{\text {Umed-Epi }}$ in the central and northern Aegean Sea suggest high $\mathrm{C}_{\text {org }}$ fluxes, which however are not reflected in the estimated PP-based values. The eventual underestimation of $\mathrm{C}_{\text {org }}$ fluxes in these more marginal areas is likely caused by additional lateral OM input and the focusing of organic matter in isolated small basins. In fact, the northern and central Aegean Sea experiences high OM input from terrestrial sources through outflow of north Aegean rivers and the Black Sea (Aksu et al., 1999; Tsiaras et al., 2012). In contrast, the measured main redox boundary depth and the TOC contents do not indicate a higher supply in organic matter. However, sediment trap data from the northern Aegean Sea (Lykousis et al., 2002) reveal $\mathrm{C}_{\text {org }}$ fluxes of $35-81 \mathrm{~g} \mathrm{C} \mathrm{m}^{-2} \mathrm{a}^{-1}$, which are 3-10 times higher than estimated values solely based on PP-based vertical fluxes. Although the high measured values can be partly attributed to the short sampling interval of 2 months in late spring and thus to elevated vertical fluxes during the spring bloom, elevated year-round lateral $\mathrm{C}_{\text {org }}$ fluxes can be expected, but of a clearly lower dimension. The measured ratio of primary to reworked OM in the sediment at this site is around 60-70\% (Lykousis et al., 2002; Poulos, 2009), which leaves the PP as the main source of the $C_{\text {org }}$ fluxes to the deep sea. Similar results have been derived for canyon systems of the Gulf of Lion where OM resuspension, shelf-to-slope cascading, and channeling results in significantly higher observed than PP-derived estimated $\mathrm{C}_{\text {org }}$ fluxes (Heussner et al., 2006; Pusceddu et al., 2010, Pasqual et al., 2010). Even in open slope settings, resuspended OM can significantly contribute to the total $\mathrm{C}_{\text {org }}$ flux (McCave et al., 2001; Tesi et al., 2010; Stabholz et al., 2013).

Despite these biases, it appears reasonable to develop a $\mathrm{C}_{\text {org }}$ flux transfer function at least for the more open marine settings of the western and central Mediterranean Sea and the southern Aegean Sea (Fig. 6). Here, vertical sinking of PP-derived OM appears to be the main source for $\mathrm{C}_{\text {org }}$ fluxes (Pusceddu et al., 2010) explaining the good correlation

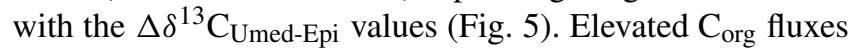
of the upwelling-affected Alboran Sea (Hernandez-Almeida et al., 2011) are reflected in rather negative $\Delta \delta^{13} \mathrm{C}_{\text {Umed-Epi }}$ values while the observed $\delta^{13} \mathrm{C}$ differences in the more oligotrophic regions of the Mallorca Channel, the Spanish slope off Barcelona, the Strait of Sicily, and the southern Aegean

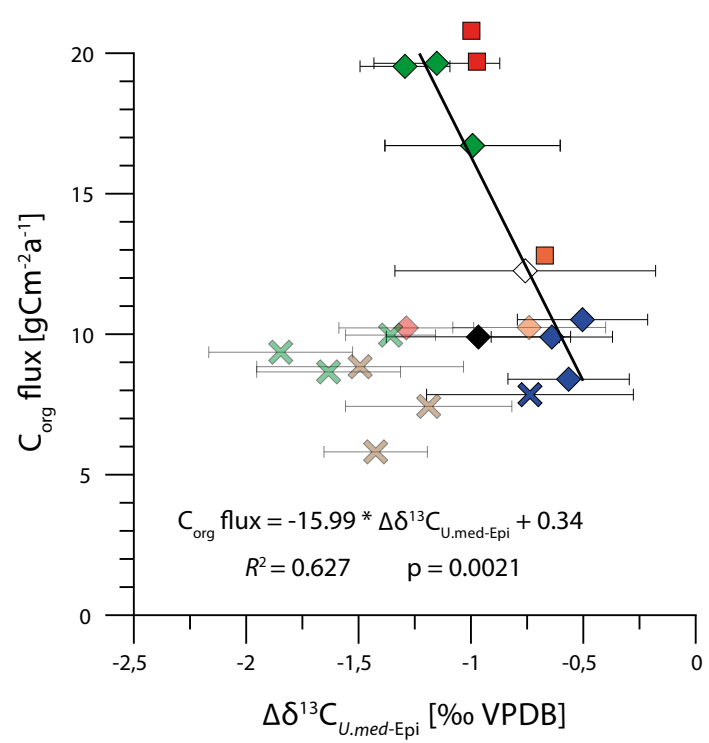

\begin{tabular}{|c|c|c|}
\hline$>$ Strait of Sicily & Spanish slope & \ North Aegean Sea \\
\hline Alboran Sea & $\square$ Gulf of Lions, canyon & X Central Aegean Sea \\
\hline Mallorca channel & $\square$ Gulf of Lions, slope & X South Aegean Sea \\
\hline
\end{tabular}

Figure 6. Correlation of the $\delta^{13} \mathrm{C}$ difference between live Uvigerina mediterranea and epifaunal taxa $\left(\Delta \delta^{13} \mathrm{C}_{\text {Umed-Epi }}\right)$ and organic carbon flux rate $\left(\mathrm{C}_{\text {org }}\right.$ flux $)$ calculated according to Antoine and Morel (1996) and Betzer et al. (1984). Transparent data from the central and northern Aegean Sea and the Gulf of Lion have been removed from the function since PP-based $\mathrm{C}_{\text {org }}$ flux values are likely underestimated because of the additional influence of lateral organic matter fluxes on the $\delta^{13} \mathrm{C}_{\text {Umed }}$ values in these areas.

Sea are lower. So, omitting the data from the northern and central Aegean Sea, and considering sediment trap data from the Gulf of Lion (Heussner et al., 2006) the derived function can be expressed as

$\mathrm{C}_{\text {org }}$ flux $=-15.99 \times \Delta \delta^{13} \mathrm{C}_{\text {Umed-Epi }}+0.34$,

with a coefficient of determination $\left(R^{2}\right)$ of 0.63 and a significance $(p)$ of 0.0021 (Fig. 6). The estimated $\mathrm{C}_{\text {org }}$ fluxes can be used to recalculate marine PP, but should be handled carefully due to the highly possible overestimation caused by lateral advection. Especially in more marginal areas, this bias can lead to unreliable recalculated PP values.

The application of this function to unstained U. mediterranea tests creates a higher range of uncertainty. The main reason for this inconsistency seems to be the relocation of fossil tests at particular sites, leading to significant contrasts between $\delta^{13} \mathrm{C}_{\text {Umed }}$ values of stained and unstained tests. For empty $U$. mediterranea tests, marked negative $\delta^{13} \mathrm{C}_{\text {Umed }}$ outliers appear at Sites 537 and 396, which has already been mentioned in Theodor et al. (2016) for the latter site. In the Alboran Sea (Sites 338 and 347) on the other hand, $\delta^{13} \mathrm{C}_{\text {Umed }}$ values of unstained tests are about $0.50 \%$ o higher than those of stained tests. Less distinct $\delta^{13} \mathrm{C}_{\mathrm{Umed}}$ differences between 
autochthonous and allochthonous tests may not be detected so easily. These potential uncertainties have to be considered in the application of the transfer function to sediment cores, particularly to down-core records from sites influenced by strong lateral transport such as canyon environments or the northern and central Aegean Sea. Likewise, the application of the transfer function to areas outside of the Mediterranean Sea may be biased by contrasting remineralization rates due to the specific oceanographic conditions, especially the higher temperatures in the Mediterranean Sea. Further refinement of this function will require an interdisciplinary effort including a larger number of direct $\mathrm{C}_{\text {org }}$ flux measurements in sediment trap deployments, which can be directly related to the obtained foraminiferal $\delta^{13} \mathrm{C}$ signals.

\section{Conclusions}

The $\delta^{13} \mathrm{C}$ signal of deep-sea benthic foraminifera from different areas of the western, central, and eastern Mediterranean Sea reflects an integration of various environmental and biological signals. The application of epifaunal benthic foraminifera as an unbiased proxy for the $\delta^{13} \mathrm{C}_{\mathrm{DIC}}$ of the surrounding water mass is ambiguous due to possible allochthonous tests, but also due to a slight species-specific difference in the microhabitat that can result in significant $\delta^{13} \mathrm{C}_{\mathrm{Epi}}$ shifts. The $\delta^{13} \mathrm{C}$ signal of the strictly epifaunal Planulina ariminensis should be preferred, in contrast to the $\delta^{13} \mathrm{C}$ signal of the less strictly epifaunal Cibicidoides pachyder$m u s$, which appears to be influenced by pore water DIC and its $\delta^{13} \mathrm{C}$ value.
The $\delta^{13} \mathrm{C}$ signal of epifaunal taxa lacks ontogenetic effects supporting results from previous studies (Dunbar and Wefer, 1984; Corliss et al., 2002; Theodor et al., 2016). Significant ontogenetic effects were recorded in the $\delta^{13} \mathrm{C}$ signal of Uvigerina mediterranea. While the ontogenetic increase of $\delta^{13} \mathrm{C}_{\text {Umed }}$ is more or less comparable $(0.11 \pm 0.03 \%$ o $100 \mathrm{\mu m}^{-1}$ ) in the western Mediterranean and the Strait of Sicily, a stronger increase and even a regional south-north trend is documented for the Aegean Sea $(0.16 \pm 0.04 \%$ o $\left.100 \mu^{-1}\right)$. In general, the $\delta^{13} \mathrm{C}$ values of $U$. mediterranea from the Aegean Sea are more negative when compared to those from the western and central Mediterranean Sea. This regional contrast cannot be reconciled with different vital and pore water effects but instead seems to be caused by enhanced residence times of bottom waters in the partly isolated small basins within the Aegean Sea. In cases of welloxygenated conditions, the $\delta^{13} \mathrm{C}_{\text {Umed }}$ signal, compared to bottom water, is mainly controlled by regional trophic contrasts and related remineralisation rates. The $\Delta \delta^{13} \mathrm{C}_{\text {Umed-Epi }}$ are clearly related to the median microhabitat depth, the depth of the redox boundary (indicating the extent of the oxygenated layer), and (to a lower extent) to the TOC of the surface sediment. Based on satellite-derived primary production estimates $\mathrm{C}_{\text {org }}$ fluxes were calculated and related to the recorded $\Delta \delta^{13} \mathrm{C}_{\text {Umed-Epi }}$ values. Comparison with sediment trap data reveals underestimation of satellite-derived $\mathrm{C}_{\text {org }}$ fluxes for the marginal areas of the central and northern Aegean Sea and the canyon systems of the Gulf of Lion. In these ecosystems, additional lateral transport of resuspended and terrestrial $\mathrm{OM}$ contributes substantially to $\mathrm{C}_{\text {org }}$ fluxes. Considering these biases, a first estimation for $\mathrm{C}_{\text {org }}$ fluxes in open-ocean settings of the Mediterranean Sea could be established.

\section{Data availability}

The main data source (stable isotope data) of this work is within the appendix. 


\section{Appendix A}

List of benthic foraminiferal taxa used in this study

$\begin{array}{ll}\text { Cibicides lobatulus (Walker and Jakob) } & \text { Nautilus lobatulus (Walker and Jacob, 1798, p. 642, pl. 14, Fig. 36) } \\ \text { Cibicidoides pachydermus (Rzehak) } & \text { Truncatulina pachyderma (Rzehak, 1886, p. 87, pl. 1, Fig. 5) } \\ \text { Planulina ariminensis (d'Orbigny) } & \text { Planulina ariminensis (d'Orbigny, 1826, p. 280, pl. 14, Figs. 1-3) } \\ \text { Uvigerina mediterranea (Hofker) } & \text { Uvigerina mediterranea (Hofker, 1932, pp. 118-121, Fig. 32) }\end{array}$

Planulina ariminensis (d'Orbigny)

Uvigerina mediterranea (Hofker, 1932, pp. 118-121, Fig. 32) 


\section{The Supplement related to this article is available online at doi:10.5194/bg-13-6385-2016-supplement.}

Acknowledgements. We would like to thank K.-C. Emeis and two anonymous referees for their helpful remarks and suggestions. We thank the ship crews and scientists of the R/V Meteor for good collaboration during cruises M40/4, M51/3, and M69/1. We give thanks to Valerie Menke for foraminifera test size measurements and Mareike Paul for selection of epifaunal specimens. We thank David Antoine for suggestions on the GlobColour data set and Jürgen Möbius for support during processing of the TOC samples. Lisa Schönborn and Günther Meyer are thanked for technical support during stable isotope measurements. This study was supported by the Deutsche Forschungsgemeinschaft, grants SCHM1180/16 and MA1942/11.

Edited by: A. Shemesh

Reviewed by: three anonymous referees

\section{References}

Adkins, J. F., McIntyre, K., and Schrag, D. P.: The Salinity, Temperature, and $\delta^{18} \mathrm{O}$ of the Glacial Deep Ocean, Science, 298, 17691773, doi:10.1126/science.1076252, 2002.

Aksu, A. E., Abrajano, T., Mudie, P. J., and Yasar, D.: Organic geochemical and palynological evidence for terrigenous origin of the organic matter in Aegean sapropel S1, Mar. Geol., 153, 303-318, doi:10.1016/S0025-3227(98)00077-2, 1999.

Androulidakis, Y. S., Kourafalou, V. H., Kresenitis, Y. N., and Zervakis, V.: Variability of deep water mass characteristics in the North Aegean Sea: The role of lateral inputs and atmospheric conditions, Deep-Sea Res. Pt. I, 67, 55-72, doi:10.1016/j.dsr.2012.05.004, 2012.

Antia, A. N., Koeve,W., Fischer, G., Blanz, T., Schulz-Bull, D., Scholten, J., Neuer, S., Kremling, K., Kuss, J., Peinert, R., Hebbeln, D., Bathmann, U., Conte, M., Fehner, U., and Zeitzschel, B.: Basin-wide particulate carbon flux in the Atlantic Ocean: regional export patterns and potential for atmospheric $\mathrm{CO}_{2}$ sequestration, Global Biogeochem. Cy., 15, 845862, doi:10.1029/2000GB001376, 2001.

Antoine, D. and Morel, A.: Oceanic primary production: 1. Adaptation of a spectral light-photosynthesis model in view of application to satellite chlorophyll observations, Global Biogeochem. Cy., 10, 43-55, doi:10.1029/95GB02831, 1996.

Bemis, B. E., Spero, H. J., Bijma, J., and Lea, D. W.: Reevaluation of the oxygen isotopic composition of planktonic foraminifera: Experimental results and revised paleotemperature equations, Paleoceanography, 13, 150-160, doi:10.1029/98PA00070, 1998.

Bernhard, J. M.: Distinguishing Live from Dead Foraminifera: Methods Review and Proper Applications, Micropaleontology, 46, 38-46, 2000.

Betzer, P. R., Showers, W. J., Laws, E. A., Winn, C. D., DiTullio, G. R., and Kroopnick, P. M.: Primary productivity and particle fluxes on a transect of the equator at $153^{\circ} \mathrm{W}$ in the Pacific Ocean, Deep-Sea Res., 31, 1-11, doi:10.1016/0198-0149(84)90068-2, 1984.
Bishop, J. K. B.: Autonomous observations of the ocean biological carbon pump, Oceanography, 22, 182-193, doi:10.5670/oceanog.2009.48, 2009.

Bosc, E., Bricaud, A., and Antoine, D.: Seasonal and interannual variability in algal biomass and primary production in the Mediterranean Sea, as derived from 4 years of SeaWiFS observations, Global Biogeochem. Cy., 18, GB1005, doi:10.1029/2003GB002034, 2004

Boyd, P. W. and Trull, T. W.: Understanding the export of biogenic particles in oceanic waters: Is there consensus?, Prog. Oceanogr., 72, 276-312, doi:10.1016/j.pocean.2006.10.007, 2007.

Brückner, S. and Mackensen, A.: Organic matter rain rates, oxygen availability, and vital effects from benthic foraminiferal $\delta^{13} \mathrm{C}$ in the historic Skagerrak, North Sea, Mar. Micropaleontol., 66, 192-207, doi:10.1016/j.marmicro.2007.09.002, 2008.

Canals, M., Company, J.B., Martín, D., Sànchez-Vidal, A., and Ramírez-Llodrà, E.: Integrated study of Mediterranean deep canyons: Novel results and future challenges, Prog. Oceanogr. 118, 1-27, doi:10.1016/j.pocean.2013.09.004, 2013.

Corliss, B. H.: Microhabitats of benthic foraminifera within deepsea sediments, Nature, 314, 435-438, doi:10.1038/314435a0, 1985.

Corliss, B. H., McCorkle, D. C., and Higdon, D. M.: A time series study of the carbon isotopic composition of deep-sea benthic foraminifera, Paleoceanography, 17, 1036, doi:10.1029/2001PA000664, 2002.

Curry, W. B. and Lohmann, G. P.: Carbon Isotopic Changes in Benthic Foraminifera from the Western South Atlantic: Reconstruction of Glacial Abyssal Circulation Patterns, Quaternary Res., 18, 218-235, doi:10.1016/0033-5894(82)90071-0, 1982.

Danovaro, R., Dinet, A., Duineveld, G., and Tselepides, A.: Benthic response to particulate fluxes in different trophic environments: a comparison between the Gulf of LionsCatalan Sea (western-Mediterranean) and the Cretan Sea (eastern-Mediterranean), Prog. Oceanogr., 44, 287-312, doi:10.1016/S0079-6611(99)00030-0, 1999.

De La Rocha, C. and Passow, U., Factors influencing the sinking of POC and the efficiency of the biological carbon pump, Deep-Sea Res. Pt. II, 54, 639-658, doi:10.1016/j.dsr2.2007.01.004, 2007.

Dunbar, R. B. and Wefer, G.: Stable isotope fractionation in benthic foraminifera from the Peruvian continental margin, Mar. Geol., 59, 215-225, doi:10.1016/0025-3227(84)90094-X, 1984.

Edgar, K. M., Pälike, H., and Wilson, P. A.: Testing the impact of diagenesis on the $\delta^{18} \mathrm{O}$ and $\delta^{13} \mathrm{C}$ of benthic foraminiferal calcite from a sediment burial depth transect in the equatorial Pacific, Paleoceanography, 28, 468-480, doi:10.1002/palo.20045, 2013.

Felix, M.: A comparison of equations commonly used to calculate organic carbon content and marine palaeoproductivity from sediment data, Mar. Geol., 347, 1-11, doi:10.1016/j.margeo.2013.10.006, 2014.

Fontanier, C., Mackensen, A., Jorissen, F. J., Anschutz, P., Licari, L., and Griveau, C.: Stable oxygen and carbon isotopes of live benthic foraminifera from the Bay of Biscay: Microhabitat impact and seasonal variability, Mar. Micropaleontol., 58, 159-183, doi:10.1016/j.marmicro.2005.09.004, 2006.

Franco-Fraguas, P., Badaraco Costa, K., and de Lima Toledo, F. A.: Stable Isotope/Test size relationship in Cibicidoides wuellerstorfi, Braz. J. Oceanogr., 59, 287-291, doi:10.1590/S1679$87592011000300010,2011$. 
Giresse, P., Buscail, R., and Charrière, B.: Late Holocene multisource material input into the Aegean Sea: depositional and post-depositional processes, Oceanol. Ac., 26, 657-672, doi:10.1016/j.oceact.2003.09.001, 2003.

Gogou, A., Sanchez-Vidal, A., Durrieu de Madron, X., Stavrakakis, S., Calafat, A. M., Stabholz, M., Psarra, S., Canals, M., Heussner, S., Stavrakaki, I., and Papathanassiou, E.: Carbon flux to the deep in three open sites of the Southern European Seas (SES), J. Mar. Syst., 129, 224-233, doi:10.1016/j.jmarsys.2013.05.013, 2014.

Grossman, E. L.: Carbon isotopic fractionation in live benthic foraminifera - comparison with inorganic precipitate studies, Geochim. Cosmochim. Ac., 48, 1505-1512, doi:10.1016/00167037(84)90406-X, 1984a.

Grossman, E. L.: Stable isotope fractionation in live benthic Foraminifera from the Southern California Borderland, Palaeogeogr. Palaeoclimatol., 47, 301-327, doi:10.1016/00310182(84)90100-7, 1984b.

Hemleben, C., Becker, T., Bellas, S., Benningsen, G., Casford, J., Cagatay, N., Emeis, K.-C., Engelen, B., Ertan, T., Fontanier, C., Friedrich, O., Frydas, D., Giunta, S., Hoffelner, H., Jorissen, F., Kahl, G., Kaszemeik, K., Lykousis, V., Meier, S., Nickel, G., Overman, J., Pross, J., Reichel, T., Robert, C., Rohling, E., Ruschmeier, W., Sakinc, M., Schiebel, R., Schmiedl, G., Schubert, K., Schulz, H., Tischnak, J., and Truscheit, T.: OstatlantikMittelmeer-Schwarzes Meer, Part 3, Cruise No.51, Leg 3, 14 November-10 December 2001, Valetta-Istanbul, METEORBerichte, Universität Hamburg, 03-1, 57 pp., 2003.

Hernández-Almeida, I. Bárcena, M.A., Flores, J. A., Sierro, F. J., Sanchez-Vidal, A., and Calafat, A.: Microplankton response to environmental conditions in the Alboran Sea (Western Mediterranean): One year sediment trap record, Mar. Micropaleontol., 78, 14-24, doi:10.1016/j.marmicro.2010.09.005, 2011.

Heussner, S., Durrieu de Madron, X., Calafat, A., Canals, M., Carbonne, J., Delsaut, N., and Saragoni, G.: Spatial and temporal variability of downward particle fluxes on a continental slope: Lessons from an 8-yr experiment in the Gulf of Lions (NW Mediterranean), Mar. Geol., 234, 63-92, doi:10.1016/j.margeo.2006.09.003, 2006.

Hieke, W., Hemleben, C., Linke, P., Türkay, M., and Weikert, H.: Mittelmeer 1998/99, Cruise No. 40, 28 October 1997-10 February 1998, METEOR-Berichte, Universität Hamburg, 99-2, 286 pp., 1999.

Holsten, J., Stott, L., and Berelson, W.: Reconstructing benthic carbon oxidation rates using $\delta^{13} \mathrm{C}$ of benthic foraminifera, Mar. Micropaleontol., 53, 117-132, doi:10.1016/j.marmicro.2004.05.006, 2004.

Hoogakker, B. A. A., Elderfield, H., Schmiedl, G., McCave, I. N., and Rickaby, R. E. M.: Glacial-interglacial changes in bottomwater oxygen content on the Portuguese margin, Nat. Geosci., 8, 40-43, doi:10.1038/NGEO2317, 2015.

Hübscher, C., Betzler, C., Grevemeyer, I.: Sedimentology, riftprocesses and neotectonic in the western Mediterranean, Cruise No. 69, 8 August-20 September 2006, Las Palmas (Spain)Cartagena (Spain)-La Valletta (Malta), METEOR-Berichte, Universität Hamburg, 99-2, 86 pp., 2010.

Huertas, I. E., Rios, A. F., Garcia-Lafuente, J., Navarro, G., Makaoui, A., Sanchez-Roman, A., Rodriguez-Galvez, S., Orbi, A., Ruiz, J., and Perez, F. F.: Atlantic forcing of the Mediter- ranean oligotrophy, Global Biogeochem. Cy., 26, Gb2022, doi:10.1029/2011gb004167, 2012.

Jorissen, F. J., de Stigter, H. C., and Widmark, J. G. V.: A conceptual model explaining benthic foraminiferal microhabitats, Mar. Micropaleontol., 26, 3-15, doi:10.1016/0377-8398(95)00047-X, 1995.

Keeling, C. D.: The Suess effect: 13Carbon-14Carbon interrelations, Environ. Int., 2, 229-300, doi:10.1016/01604120(79)90005-9, 1979.

Kitazato, H.: Foraminiferal microhabitats in four marine environments around Japan, Mar. Micropaleontol., 24, 29-41, doi:10.1016/0377-8398(94)90009-4, 1994.

Koho, K. A. and Piña-Ochoa, E.: Benthic Foraminifera: Inhabitants of low-oxygen environments, in: Anoxia: Evidence for Eukaryote Survival and Paleontological Strategies, Cellular Origin, Life in Extreme Habitats and Astrobiology, edited by: Altenbach, A. V., Bernhard, J. M., and Seckbach, J., 21, 249-285, doi:10.1007/978-94-007-1896-8_14, 2012.

Koho, K. A., García, R., de Stigter, H. C., Epping, E., Koning, E., Kouwenhoven, T. J., and van der Zwaan, G. J.: Sedimentary labile organic carbon and pore water redox control on species distribution of benthic foraminifera: A case study from LisbonSetúbal Canyon (southern Portugal), Prog. Oceanogr., 79, 55-82, doi:10.1016/j.pocean.2008.07.004, 2008.

Kuhnt, T., Schmiedl, G., Ehrmann, W., Hamann, Y., and Andersen, N.: Stable isotope composition of Holocene benthic foraminifers from the Eastern Mediterranean Sea: Past changes in productivity and deep water oxygenation, Palaeogeogr. Palaeoclimatol., 268, 106-115, doi:10.1016/j.palaeo.2008.07.010, 2008.

Lascaratos, A., Roether, W., Nittis, K., and Klein, B.: Recent changes in the Eastern Mediterranean Deep Waters: a review, Prog. Oceanogr., 44, 5-36, doi:10.1016/S0079-6611(99)00019$1,1999$.

Licari, L. and Mackensen, A.: Benthic foraminifera off West Africa $\left(1^{\circ} \mathrm{N}\right.$ to $\left.32^{\circ} \mathrm{S}\right)$ : Do live assemblages from the topmost sediment reliably record environmental variability?, Mar. Micropaleontol., 55, 205-233, doi:10.1016/j.marmicro.2005.03.001, 2005.

Linke, P. and Lutze, G. F.: Microhabitat preferences of benthic foraminifera a static concept or a dynamic adaptation to optimize food acquisition?, Mar. Micropaleontol., 20, 215-234, doi:10.1016/0377-8398(93)90034-U, 1993.

López-Sandoval, D. C., Fernández, A., and Marañón, E.: Dissolved and particulate primary production along a longitudinal gradient in the Mediterranean Sea, Biogeosciences, 8, 815-825, doi:10.5194/bg-8-815-2011, 2011.

Lutze, G. F. and Thiel, H.: Epibenthic foraminifera from elevated microhabitats: Cibicidoides wuellerstorfi and Planulina ariminensis, J. Foramin. Res., 19, 153-158, doi:10.2113/gsjfr.19.2.153, 1989.

Lykousis, V., Chronis, G., Tselepides, A., Price, B., Theocharis, A., Siokou-Frangou, I., Van Wambeke, F., Danovaro, R., Stavrakakis, S., Duineveld, G., Georgopoulos, D., Ignatiades, L., Souvermezoglou, E., and Voutsinou-Taliadouri, F.: Major outputs of the recent multidisciplinary biogeochemical researches undertaken in the Aegean Sea, J. Mar. Syst., 33/34, 313-334, doi:10.1016/S0924-7963(02)00064-7, 2002.

Lyle, M.: The brown-green color transition in marine sediments: A marker of the Fe(III)-Fe(II) redox boundary, Limnol. Oceanogr., 28, 1026-1033, doi:10.4319/lo.1983.28.5.1026, 1983. 
Mackensen, A.: On the use of benthic foraminiferal $\delta^{13} \mathrm{C}$ in palaeoceanography: constraints from primary proxy relationships, in: Biogeochemical Controls on Palaeoceanographic Environmental Proxies, edited by: Austin, W. E. N. and James, R. H., Geological Society, London, Special Publications 303, 121-133, doi:10.1144/SP303.9, 2008.

Mackensen, A. and Bickert, T.: Stable carbon isotopes in benthic foraminifera: Proxies for deep and bottom water circulation and new production, in: Use of proxies in paleoceanography: Examples from the South Atlantic, edited by: Fischer, G. and Wefer, G., Springer, Berlin, Heidelberg, 229-254, doi:10.1007/978-3642-58646-0_9, 1999.

Mackensen, A. and Douglas, R. G.: Down-core distribution of live and dead deep-water benthic foraminifera in box cores from the Weddell Sea and the California continental borderland, Deep-Sea Res., 36, 879-900, doi:10.1016/0198-0149(89)90034-4, 1989.

Mackensen, A. and Licari, L.: Carbon isotopes of live benthic foraminifera from the eastern South Atlantic Ocean: Sensitivity to organic matter rain rates and bottom water carbonate saturation state, in: The South Atlantic in the Late Quaternary - Reconstruction of material budget and current systems, edited by: Wefer, G., Mulitza, S., and Rathmeyer, V., Springer-Verlag, Berlin, 623-644, doi:10.1007/978-3-642-18917-3_27, 2004.

Mackensen, A., Schumacher, S., Radke, J., and Schmidt, D. N.: Microhabitat preferences and stable carbon isotopes of endobenthic foraminifera: clue to quantitative reconstruction of oceanic new production?, Mar. Micropaleontol., 40, 233-258, doi:10.1016/S0377-8398(00)00040-2, 2000.

Marchitto, T. M., Curry, W. B., Lynch-Stieglitz, J., Bryan, S. P., Cobb, K. M., and Lund, D. C.: Improved oxygen isotope temperature calibrations for cosmopolitan benthic foraminifera, Geochim. Cosmochim. Ac., 130, 1-11, doi:10.1016/j.gca.2013.12.034, 2014.

Martin, J. H., Knauer, G. A., Karl, D. M., and Broenkow, W. W.: VERTEX: carbon cycling in the northeast Pacific, Deep-Sea Res., 34, 267-285, doi:10.1016/0198-0149(87)90086-0, 1987.

McCave, I. N., Hall, I. R., Antia, A. N., Chou, L., Dehairs, F., Lampitt, R. S., Thomsen, L., van Weering, T. C. E., and Wollast, R.: Distribution, composition and flux of particulate material over the European margin at $47^{\circ}-50^{\circ} \mathrm{N}$, Deep-Sea Res. Pt. II, 48, 3107-3139, doi:10.1016/S0967-0645(01)00034-0, 2001.

McConnaughey, T.: ${ }^{13} \mathrm{C}$ and ${ }^{18} \mathrm{O}$ isotopic disequilibrium in biological carbonates: I. Patterns, Geochim. Cosmochim. Ac., 53, 151162, doi:10.1016/0016-7037(89)90282-2, 1989a.

McConnaughey, T.: ${ }^{13} \mathrm{C}$ and ${ }^{18} \mathrm{O}$ isotopic disequilibrium in biological carbonates: II. in vitro simulation of kinetic isotope effects, Geochim. Cosmochim. Ac., 53, 163-171, doi:10.1016/00167037(89)90283-4, 1989b.

McCorkle, D. C. and Emerson, S. R.: The relationship between pore water carbon isotopic composition and bottom water oxygen concentration, Geochim. Cosmochim. Ac., 52, 1169-1178, doi:10.1016/0016-7037(88)90270-0, 1988.

McCorkle, D. C., Bernhard, J. M., Hintz, C. J., Blanks, J. K., Chandler, G. T., and Shaw, T. J.: The carbon and oxygen stable isotopic composition of cultured benthic foraminifera, in: Biogeochemical Controls on Palaeoceanographic Environmental Proxies, edited by: Austin, W. E. N. and James, R. H., Geological Society, London, Special Publications 303, 135-154, doi:10.1144/SP303.10, 2008.
McCorkle, D. C., Corliss, B. H., and Farnham, C. A.: Vertical distributions and stable isotopic compositions of live (stained) benthic foraminifera from the North Carolina and California continental margins, Deep-Sea Res. Pt. I, 44, 983-1024, doi:10.1016/S09670637(97)00004-6, 1997.

McCorkle, D. C., Emerson, S. R., and Quay, P. D.: Stable carbon isotopes in marine porewaters, Earth Planet. Sc. Lett., 74, 13-26, doi:10.1016/0012-821X(85)90162-1, 1985.

McCorkle, D. C., Keigwin, L. D., Corliss, B. H., and Emerson, S. R.: The influence of microhabitats on the carbon isotopic composition of deep-sea benthic foraminifera, Paleoceanography, 5 , 161-185, doi:10.1029/PA005i003p00295, 1990.

MedAtlas: Mediterranean Hydrographic Atlas (Mast Supporting Initiative; MAS2-CT93-0074), CD-ROM, 1997.

Möbius, J., Lahajnar, N., and Emeis, K.-C.: Diagenetic control of nitrogen isotope ratios in Holocene sapropels and recent sediments from the Eastern Mediterranean Sea, Biogeosciences, 7, 3901-3914, doi:10.5194/bg-7-3901-2010, 2010a.

Möbius, J Lahajnar, N., and Emeis, K.-C.: Chemical composition of surface sediment samples from the Eastern Mediterranean Sea, doi:10.1594/PANGAEA.754732, 2010b.

Moutin, T. and Raimbault, P.: Primary production, carbon export and nutrients availability in western and eastern Mediterranean Sea in early summer 1996 (MINOS cruise), J. Marine Syst., 33/34, 273-288, doi:10.1016/S0924-7963(02)00062-3, 2002.

Ohga, T. and Kitazato, H.: Seasonal changes in bathyal foraminiferal populations in response to the flux of organic matter (Sagami Bay, Japan), Terra Nova, 9, 33-37, doi:10.1046/j.1365-3121.1997.d01-6.x, 1997.

Packard, T. T. and Gómez, M.: Modeling vertical carbon flux from zooplankton respiration, Prog. Oceanogr., 110, 59-68, doi:10.1016/j.pocean.2013.01.003, 2013.

Pahnke, K. and Zahn, R.: Southern hemisphere water mass conversion with North Atlantic climate variability, Science, 307, 17411746, doi:10.1126/science.1102163, 2005.

Pasqual, C., Sanchez-Vidal, A., Zúñiga, D., Calafat, A., Canals, M., Durrieu de Madron, X., Puig, P., Heussner, S., Palanques, A., and Delsaut, N.: Flux and composition of settling particles across the continental margin of the Gulf of Lion: the role of dense shelf water cascading, Biogeosciences, 7, 217-231, doi:10.5194/bg-7217-2010, 2010.

Pierre, C.: The oxygen and carbon isotope distribution in the Mediterranean water masses, Mar. Geol., 153, 41-55, doi:10.1016/S0025-3227(98)00090-5, 1999.

Pinardi, N. and Masetti, E.: Variability of the large scale general circulation of the Mediterranean Sea from observations and modelling: a review, Palaeogeogr. Palaeoclimatol., 158, 153-173, doi:10.1016/S0031-0182(00)00048-1, 2000.

Pinardi, N., Zavatarelli, M., Adani, M., Coppini, G., Fratianni, C., Oddo, P., Simoncelli, S., Tonani, M, Lyubartsev, V., Dobricic, S., and Bonaduce, A.: Mediterranean Sea large-scale low-frequency ocean variability and water mass formation rates from 1987 to 2007: A retrospective analysis, Prog. Oceanogr. 132, 318-332, doi:10.1016/j.pocean.2013.11.003, 2015.

Poulos, S. E.: Origin and distribution of the terrigenous component of the unconsolidated surface sediment of the Aegean floor: A synthesis, Cont. Shelf Res., 29, 2045-2060, doi:10.1016/j.csr.2008.11.010, 2009. 
Puig, P. and Palanques, A.: Temporal variability and composition of settling particle fluxes on the Barcelona continental margin (Northwestern Mediterranean), J. Mar. Res., 56, 639-654, doi:10.1357/002224098765213612, 1998.

Pujo-Pay, M., Conan, P., Oriol, L., Cornet-Barthaux, V., Falco, C., Ghiglione, J.-F., Goyet, C., Moutin, T., and Prieur, L.: Integrated survey of elemental stoichiometry $(\mathrm{C}, \mathrm{N}, \mathrm{P})$ from the western to eastern Mediterranean Sea, Biogeosciences, 8, 883899, doi:10.5194/bg-8-883-2011, 2011.

Pusceddu, A., Bianchelli, S., Canals, M., Sanchez-Vidal, A., Durrieu de Madron, X., Heussner, S., Lykousis, V., de Stigter, H., Trincardi, F., and Danovaro, R.: Organic matter in sediments of canyons and open slopes of the Portuguese, Catalan, Southern Adriatic and Cretan Sea margins, Deep-Sea Res. Pt. I, 57, 441457, doi:10.1016/j.dsr.2009.11.008, 2010a.

Quay, P. D., Tilbrook, B., and Wong, C. S.: Oceanic Uptake of Fossil Fuel CO2: Carbon-13 Evidence, Science, 256, 74-79, doi:10.1126/science.256.5053.74, 1992.

Rathburn, A. E. and Corliss, B. H.: The ecology of living (stained) deep-sea benthic foraminifera from the Sulu Sea, Paleoceanography, 9, 87-150, doi:10.1029/93PA02327, 1994.

Rathburn, A. E., Corliss, B. H., Tappa, K. D., and Lohmann, K. C.: Comparisons of the ecology and stable isotopic compositions of living (stained) benthic foraminifera from the Sulu and South China Seas, Deep-Sea Res. Pt. I, 43, 1617-1646, doi:10.1016/S0967-0637(96)00071-4, 1996.

Rhein, M., Send, U., Klein, B., and Krahmann, G.: Interbasin deep water exchange in the western Mediterranean, J. Geophys. Res., 104, 23495-23508, doi:10.1029/1999JC900162, 1999.

Roether, W., Manca, B. B., Klein, B., Bregant, D., Georgopoulos, D., Beitzel, V., Kovacevic, V., and Luchetta, A.: Recent changes in eastern Mediterranean deep waters, Science, 271, 333-335, doi:10.1126/science.271.5247.333, 1996.

Roether, W., Klein, B., Manca, B. B., Theocharis, A., and Kioroglou, S.: Transient Eastern Mediterranean deep waters in response to the massive dense-water output of the Aegean Sea in the 1990s, Prog. Oceanogr., 74, 540-571, doi:10.1016/j.pocean.2007.03.001, 2007.

Rutgers van der Loeff, M. M.: Oxygen in pore waters of deepsea sediments, Philos. Trans. R. Soc. Lond. A, 331, 69-84, doi:10.1098/rsta.1990.0057, 1990.

Sanchez-Vidal, A., Calafat, A., Canals, M., and Fabres, J.: Particle fluxes in the Almeria-Oran Front: control by coastal upwelling and sea surface circulation, J. Mar. Syst., 52, 89-106, doi:10.1016/j.jmarsys.2004.01.010, 2004.

Sanchez-Vidal, A., Calafat, A., Canals, M., Frigola, J., and Fabres, J.: Particle fluxes and organic carbon balance across the Eastern Alboran Sea (SW Mediterranean Sea), Cont. Shelf Res., 25, 609_ 628, doi:10.1016/j.csr.2004.11.004, 2005.

Schilman, B., Almogi-Labin, A., Bar-Matthews, M., and Luz, B.: Late Holocene productivity and hydrographic variability in the eastern Mediterranean inferred from benthic foraminiferal stable isotopes, Paleoceanography, 18, 1064, doi:10.1029/2002PA000813, 2003.

Schmiedl, G. and Mackensen, A.: Multispecies stable isotopes of benthic foraminifers reveal past changes of organic matter decomposition and deepwater oxygenation in the Arabian Sea, Paleoceanography, 21, PA4213, doi:10.1029/2006PA001284, 2006.
Schmiedl, G., de Bovée, F., Buscail, R., Charrière, B., Hemleben, C., Medernach, L., and Picon, P.: Trophic control of benthic foraminiferal abundance and microhabitat in the bathyal Gulf of Lions, western Mediterranean Sea, Mar. Micropaleontol., 40, 167-188, doi:10.1016/S0377-8398(00)00038-4, 2000.

Schmiedl, G., Pfeilsticker, M., Hemleben, C., and Mackensen, A.: Environmental and biological effects on the stable isotope composition of recent deep-sea benthic foraminifera from the western Mediterranean Sea, Mar. Micropaleontol., 51, 129-152, doi:10.1016/j.marmicro.2003.10.001, 2004.

Schroeder, K., Gasparini, G. P., Tangherlini, M., and Astraldi, M.: Deep and intermediate water in the Western Mediterranean under the influence of the Eastern Mediterranean Transient, Geophys. Res. Lett., 33, L21607, doi:10.1029/2006GL027121, 2006.

Schroeder, K., Ribotti, A., Borghini, M., Sorgente, R., Perilli, A., and Gasparini, G. P.: An extensive western Mediterranean deep water renewal between 2004 and 2006, Geophys. Res. Lett., 35, L18605, doi:10.1029/2008GL035146, 2008.

Schumacher, S., Jorissen, F. J., Mackensen, A., Gooday, A. J., and Pays, O.: Ontogenetic effects on stable carbon and oxygen isotopes in tests of live (Rose Bengal stained) benthic foraminifera from the Pakistan continental margin, Mar. Micropaleontol., 76, 92-103, doi:10.1016/j.marmicro.2010.06.002, 2010.

Send, U., Font, J., Krahmann, G., Millot, C., Rhein, M., and Tintore, J.: Recent advances in observing the physical oceanography of the western Mediterranean Sea, Prog. Oceanogr., 44, 37-64, doi:10.1016/S0079-6611(99)00020-8, 1999.

Shackleton, N. J. and Opdyke, N. D.: Oxygen Isotope and Palaeomagnetic Stratigraphy of Equatorial Pacific Core V28-238: Oxygen Isotope Temperatures and Ice Volumes on a 105 Year and 106 Year Scale, Quaternary Res., 3, 39-55, doi:10.1016/00335894(73)90052-5, 1973.

Siokou-Frangou, I., Bianchi, M., Christaki, U., Christou, E. D., Giannakourou, A., Gotsis, O., Ignatiades, L., Pagou, K., Pitta, P., Psarra, S., Souvermezoglou, E., Van Wambeke, F., and Zervakis, V.: Carbon flow in the planktonic food web along a gradient of oligotrophy in the Aegean Sea (Mediterranean Sea), J. Mar. Syst., 33/34, 335-353, doi:10.1016/S0924-7963(02)000659, 2002.

Skliris, N., Mantziafou, A., Sofianos, S., and Gkanaos, A.: Satellitederived variability of the Aegean Sea ecohydrodynamics, Cont. Shelf Res. 30, 403-418, doi:10.1016/j.csr.2009.12.012, 2010.

Stabholz, M., Durrieu de Madron, X., Canals, M., Khripounoff, A., Taupier-Letage, I., Testor, P., Heussner, S., Kerhervé, P., Delsaut, N.,. Houpert, L, Lastras, G., and Dennielou, B.: Impact of openocean convection on particle fluxes and sediment dynamics in the deep margin of the Gulf of Lions, Biogeosciences, 10, 10971116, doi:10.5194/bg-10-1097-2013, 2013.

Stott, L. D., Berelson, W., Douglas, R., and Gorsline, D.: Increased dissolved oxygen in Pacific intermediate waters due to lower rates of carbon oxidation in sediments, Nature, 407, 367-370, doi:10.1038/35030084, 2000.

Suess, E.: Particulate organic carbon flux in the oceans - surface productivity and oxygen utilization, Nature, 288, 260-263, doi:10.1038/288260a0, 1980.

Tanhua, T., Hainbucher, D., Schroeder, K., Cardin, V., Álvarez, M., and Civitarese, G.: The Mediterranean Sea system: a review and an introduction to the special issue, Ocean Sci., 9, 789-803, doi:10.5194/os-9-789-2013, 2013. 
Tesi, T., Puig, P., Palanques, A., and Goñi, M.A.: Lateral advection of organic matter in cascading-dominated submarine canyons, Prog. Oceanogr., 84, 185-203, doi:10.1016/j.pocean.2009.10.004, 2010.

Theodor, M., Schmiedl, G., and Mackensen, A.: Stable isotope composition of deep-sea benthic foraminifera under contrasting trophic conditions in the western Mediterranean Sea, Mar. Micropaleontol., 124, 16-28, doi:10.1016/j.marmicro.2016.02.001, 2016.

Tsiaras, K. P., Kourafalou, V. H., Raitsos, D. E., Triantafyllou, G., Petihakis, G., and Korres, G.: Inter-annual productivity variability in the North Aegean Sea: Influence of thermohaline circulation during the Eastern Mediterranean Transient, J. Mar. Syst., 96/97, 72-81, doi:10.1016/j.jmarsys.2012.02.003, 2012.

Uitz, J., Huot, Y., Bruyant, F., Babin, M., and Claustre, H.: Relating phytoplankton photophysiological properties to community structure on large scales, Limnol. Oceanogr., 53, 614-630, doi:10.4319/ lo.2008.53.2.0614, 2008.

Velaoras, D. and Lascaratos, A.: Deep water mass characteristics and interannual variability in the North and Central Aegean Sea, J. Mar. Syst., 53, 59-85, doi:10.1016/j.jmarsys.2004.05.027, 2005.

Walton, W. R.: Techniques for recognition of living foraminifera, Contributions from the Cushman Foundation for Foraminiferal Research, 3, 56-60, 1952.
Wüst, G.: On the vertical circulation of the Mediterranean Sea, J. Geophys. Res. 66, 3261-3271, doi:10.1029/JZ066i010p03261, 1961.

Zahn, R., Winn, K., and Sarnthein, M.: Benthic Foraminiferal $\delta^{13} \mathrm{C}$ and accumulation rates of organic Carbon: Uvigerina peregrina group and Cibicidoides wuellerstorfi, Paleoceanography, 1, 27 42, doi:10.1029/PA001i001p00027, 1986.

Zervakis, V., Krasakopoulou, E., Georgopoulos, D., and Souvermezoglou, E.: Vertical diffusion and oxygen consumption during stagnation periods in the deep North Aegean, Deep-Sea Res. Pt. I, 50, 53-71, doi:10.1016/S0967-0637(02)00144-9, 2003.

Zúñiga, D., Calafat, A., Sanchez-Vidal, A., Canals, M., Price, B., Heussner, S., and Miserocchi, S.: Particulate organic carbon budget in the open Algero-Balearic Basin (Western Mediterranean): Assessment from a one-year sediment trap experiment, Deep-Sea Res. Pt. I, 54, 1530-1548, doi:10.1016/j.dsr.2007.06.001, 2007.

Zúñiga, D., Calafat, A., Heussner, S., Miserocchi, S., SanchezVidal, A., Garcia-Orellana, J., Canals, M., Sánchez-Cabeza, J.A., Carbonne, J., Delsaut, N., and Saragoni, G.: Compositional and temporal evolution of particle fluxes in the open AlgeroBalearic basin (Western Mediterranean), J. Mar. Syst., 70, 196214, doi:10.1016/j.jmarsys.2007.05.007, 2008. 